\title{
Processing and electrochemical performance of manganese-doped lanthanum-strontium chromite in oxidizing and reducing atmospheres
}

\author{
Sapna Gupta ${ }^{\mathrm{a}}$, Yu Zhong ${ }^{\mathrm{b}}$, Manoj Mahapatra ${ }^{\mathrm{a}}$ and Prabhakar Singh ${ }^{\mathrm{a}^{*}}$ \\ ${ }^{a}$ Materials Science and Engineering, University of Connecticut, Storrs, CT 06268 \\ ${ }^{\mathrm{b}}$ Mechanical and Materials Engineering, Florida International University, Miami, FL 33174
}

\begin{abstract}
:
This study reports the role of oxygen partial pressure $\left(\mathrm{PO}_{2}\right)$ on the microstructural changes and compound formation during the exposure of $\left(\mathrm{La}_{0.75} \mathrm{Sr}_{0.25}\right)_{0.95} \mathrm{Cr}_{0.7} \mathrm{Mn}_{0.3} \mathrm{O}_{3}(\mathrm{LSCM} 73)$ to $1400^{\circ} \mathrm{C}$ to emulate oxygen transport membrane device fabrication. Results of electrochemical testing of LSCM73+8YSZ//8YSZ//LSCM73+8YSZ symmetrical cells, is also reported at $950^{\circ} \mathrm{C}$ with time for $80 \mathrm{~h}$ in oxidizing (air) and reducing atmospheres $\left(\mathrm{Ar}-3 \% \mathrm{H}_{2}-3 \% \mathrm{H}_{2} \mathrm{O}\right)$. Our results from elevated temperature exposure studies show a decrease in the density during exposure to reducing atmospheres due to the absence of liquid phase assisted sintering and inability to form $\mathrm{SrCrO}_{4}$. Formation of rhombohedral structure and $\mathrm{MnCr}_{2} \mathrm{O}_{4}$ spinel phase is evident in air whereas $\mathrm{Mn}_{3} \mathrm{O}_{4}$ phase formation occurs along with lattice transformation to cubic structure at lower $\mathrm{PO}_{2}$. Our experimental results are in agreement with LSCM73 phase diagram constructed using Thermo-Calc. Stable electrochemical performance is obtained in air and in reducing atmosphere, non- ohmic resistance increases with time which is attributed to Sr-segregation on LSCM73 surface and interaction between LSCM/8YSZ. No delamination of the electrode layer is observed in both oxidizing and reducing atmosphere.
\end{abstract}

* Corresponding author. 44 Weaver Road, Storrs Mansfield, CT 06269-5233, USA. Tel.: +1 860486 8379; fax: +1 8604868378 .

Email address: singh@engr.uconn.edu 
Keywords: Oxygen transport membrane, LSCM73, Processing, Thermo-Calc, Electrochemical performance 


\section{Introduction}

The world energy council projects primary energy demand to increase dramatically in the future as population grows and developing nations elevate their living standards. Finding an effective and timely solution to the emerging global climate change and related environmental issues are universally recognized as the major challenge of this decade. High temperature $\left(\geq 650^{\circ} \mathrm{C}\right)$ solid-state electrochemical devices such as oxygen transport membrane (OTM) enables clean and efficient utilization of fossil fuels via oxy-combustion [1-2]. The technology can be adapted globally to enhance energy efficiency, reduce carbon foot print and extend the fuel reserve for future [1-4]. OTM system is also advantageous for tonnage oxygen production and syngas production which can be further processed for hydrogen production via water gas shift reaction [3]. The syngas can also be converted into liquid fuels for transportation via Fischer-Tropsch process [5].

Fig. 1 shows a schematic of oxygen transport membrane. The system consist of three layers i.e. air electrode (surface exchange layer), oxygen transport membrane and fuel electrode (intermediate layer) [6]. Oxygen molecules from air dissociate into oxygen ions at the air electrode, migrate through the membrane, and recombine with the electron to form oxygen molecule on the fuel side [7]. The driving force for the selective oxygen transport is the existence of oxygen partial pressure gradient. Air and fuel electrodes are used to enhance

surface exchange kinetics and improve the oxygen flux performance of OTM system [7]. Wide spread implementation of the aforesaid, however, remains critically limited by the current unfavorable economics, unproven reliability and lack of longevity.

Chemical/structural/redox stability and high ionic as well as electronic conductivity have been identified as one of the key requirements for oxygen transport membrane and fuel 
electrode [8-9]. Ni-YSZ is conventionally used as the fuel electrode for SOFC due to its excellent electro-catalytic activity, electronic and ionic conductivity and thermal expansion match with the electrolyte. However, carbon deposition, volume change during redox cycling and susceptibility to sulphur poisoning are the limitations of Ni-YSZ [10]. To overcome the limitations of Ni-YSZ, mixed ionic and electronic conducting perovskites with/without fluorite phase are being considered as an alternative SOFC anode and membrane/fuel electrode for OTM device [11-12]. This paper focuses on materials development for oxygen transport membrane (OTM) system. However, the results can also be utilized for the development of SOFC fuel electrode.

Lanthanum chromite based perovskites have been studied extensively as an oxygen transport membrane and fuel electrode [13-26]. This is due to its high chemical and structural stability at high temperatures in oxidizing as well as reducing atmospheres. Lanthanum chromite is commonly doped with alkaline earth metal at A-site and transition metal at B-site for improving its electrical conductivity, electrochemical performance, thermal expansion coefficient and densification. The dopants, on the other hand, have also been found to deteriorate the structural and thermo-chemical stability of these materials specifically in reducing atmosphere $\left(\leq 10^{-10} \mathrm{~atm}\right)$. A review article is recently published on the effect of $\mathrm{A}$ and B-site dopants on the structure-thermal-electrical-mechanical properties of lanthanum chromite based materials for oxygen transport membrane by Gupta et al. [16].

$\mathrm{La}_{0.75} \mathrm{Sr}_{0.25} \mathrm{Cr}_{1-\mathrm{x}} \mathrm{Mn}_{\mathrm{x}} \mathrm{O}_{3}$ (LSCMx) is being investigated for fuel side electrode and oxygen transport membrane (OTM) as it provides the combination of high electrochemical activity, high electrical conductivity and good thermal expansion match with 8 YSZ [16-19, 2530]. LSCMx is also identified as promising fuel electrode for direct utilization of hydrocarbon 
fuels [27]. The electrode polarization resistance for $\mathrm{La}_{0.75} \mathrm{Sr}_{0.25} \mathrm{Cr}_{0.5} \mathrm{Mn}_{0.5} \mathrm{O}_{3-\delta}(\mathrm{LSCM} 55)$ is 0.2 $\Omega \mathrm{cm}^{2}$ at $900^{\circ} \mathrm{C}$ in $97 \% \mathrm{H}_{2}-3 \% \mathrm{H}_{2} \mathrm{O}$, comparable to $\mathrm{Ni} / \mathrm{YSZ}$ cermets [30]. The conductivity of $\mathrm{La}_{0.75} \mathrm{Sr}_{0.25} \mathrm{Cr}_{0.5} \mathrm{Mn}_{0.5} \mathrm{O}_{3}$ is $38 \mathrm{~S} \mathrm{~cm}^{-1}$ at $900^{\circ} \mathrm{C}$ and remains same for $\mathrm{PO}_{2}$ values above $10^{-10}$ atm [29-30]. However, further lowering of $\mathrm{PO}_{2}$ to $\sim 10^{-21}$ atm, the conductivity decreases to 1.5 $\mathrm{S} \mathrm{cm}^{-1}$ [29-30]. The thermal expansion coefficient (TEC) of LSCM55 is $9.3 \times 10^{-6} \mathrm{~K}^{-1}$ in air in the temperature range of $64-956^{\circ} \mathrm{C}$. The TEC is comparable to $8 \mathrm{YSZ}\left(10.3 \times 10^{-6} \mathrm{~K}^{-1}\right)$, a most commonly used oxygen ion conducting fluorite phase [31].

For lanthanum chromite based materials, density increases with decreasing oxygen partial pressure [32-33]. Because, the vapor pressure of $\mathrm{CrO}_{3}$ significantly decreases in reducing atmospheres. Subsequently, $\mathrm{Cr}_{2} \mathrm{O}_{3}$ deposition at the inter-particle necks is inhibited resulting in higher densification [32-33]. The sintering behavior of A-site doped lanthanum chromite based materials is well known in the literature [16].

As mentioned above, these materials are further doped at B-site to improve the structural-thermal-electrical properties as required for OTM system. However, the sintering behavior of simultaneously A-site and B-site doped $\mathrm{LaCrO}_{3}$ is not investigated in the literature. In this study, we report the sintering and electrochemical behavior of manganese-doped lanthanum-strontium chromite, which is one of the most promising candidates for oxygen transport membrane and fuel electrode. However, LSCMx with higher Mn-doping level destabilizes in reducing atmosphere. For example, $(\mathrm{La}, \mathrm{Sr})_{2} \mathrm{MnO}_{4}$ and $\mathrm{MnO}$ secondary phases have been detected for LSCM55 when exposed to $900^{\circ} \mathrm{C}$ and $10^{-20}$ atm [34]. Formation of MnCr-O spinel $\left(\mathrm{MnCr}_{2} \mathrm{O}_{4}\right)$ has also been indicated in LSCM55 [35]. In reducing atmosphere, the spinel phase reduces to $\mathrm{MnO}$ [35-36]. The results exhibit that LSCMx with high Mn doping level (LSCM55) is not stable in reducing atmosphere [16, 35-36]. Furthermore, it is identified 
in the recently published review article that B-site (e.g. Mn) doping level is good to be restricted ( $\leq 30 \mathrm{~mol} . \%)$ from stability point of view [16]. However, in the reported literature, LSCMx is not investigated with higher Cr: Mn ratio or lower Mn doping level under OTM processing and operating conditions. Therefore, a composition with lower concentration of $\mathrm{Mn}$ i.e. $\left(\mathrm{La}_{0.75} \mathrm{Sr}_{0.25}\right)_{0.95} \mathrm{Cr}_{0.7} \mathrm{Mn}_{0.3} \mathrm{O}_{3-\delta}(\mathrm{LSCM} 73)$ is chosen for this study. A-site deficient composition is chosen for this study to avoid the Sr-segregation which is likely to occur in lanthanum strontium manganite/chromite based materials [16,37]. Furthermore, A-site deficiency is found to be beneficial to avoid the interaction of lanthanum strontium manganite/chromite based materials with stabilized zirconia fluorite phase to form insulating phase such as $\mathrm{La}_{2} \mathrm{Zr}_{2} \mathrm{O}_{7}$ and $\mathrm{SrZrO}_{3}[16,38]$. Sintering behavior and microstructure analysis of LSCM73 is examined under simulating OTM fabrication conditions $\left(\sim 1400^{\circ} \mathrm{C}\right.$ and $\mathrm{PO}_{2} \sim 0.21$ $\left.10^{-10} \mathrm{~atm}\right)$. On the other hand, electrochemical impedance measurement is performed at lower temperature under simulating anodic OTM operation conditions $\left(\sim 950^{\circ} \mathrm{C}\right.$ and $\left.\sim 10^{-17} \mathrm{~atm}\right)$.

\section{Experimental Procedure}

\section{$2.1\left(\mathrm{La}_{0.75} \mathrm{Sr}_{0.25}\right)_{0.95} \mathrm{Cr}_{0.7} \mathrm{Mn}_{0.3} \mathrm{O}_{3-\delta}$ synthesis}

LSCM73 powder was obtained from Praxair Inc. The particle size distribution of the powder was $\mathrm{D}_{50}=1.34 \mu \mathrm{m}$. The powder was uniaxially pressed into cylindrical pellets. Subsequently, LSCM73 powder was also mixed with $0.5 \% \mathrm{SrCrO}_{4}$ to understand the effect of $\mathrm{SrCrO}_{4}$ on densification and validate our results and hypothesis. The pellets were bisque fired at $1100^{\circ} \mathrm{C}$ for $4 \mathrm{~h}$ and then, sintered in air, $\mathrm{N}_{2}\left(\sim 10^{-5}\right.$ atm $)$ and $\mathrm{Ar}-3 \% \mathrm{H}_{2}-3 \% \mathrm{H}_{2} \mathrm{O}\left(\sim 10^{-10}\right.$ atm $)$ atmosphere at $1400^{\circ} \mathrm{C}$ with $10 \mathrm{~h}$ dwell time. Samples were cooled in the flowing gas environment to ensure the maintenance of the oxygen pressure during cooling. 


\subsection{Characterization}

Density of all the samples was measured using Archimedes principle. The microstructural analysis was conducted using scanning electron microscope (FEI - ESEM Quanta 250, Hillsboro, $\mathrm{OH})$. Energy dispersive spectroscopy (EDS) attached to the SEM was used for elemental compositional analysis.

X-ray diffraction (BRUKER-D8 ADVANCE, Bruker AXS Inc. Madison, WI) technique was used to determine the crystal structure of LSCM73 and secondary compounds, if any, sintered in different gas atmospheres. The scan step was $0.02^{\circ}$ using $\mathrm{CuK}_{\alpha}$ radiation $(\lambda=1.5406$ $\AA$ ).

\subsection{Symmetric cell fabrication}

LSCM73 is predominantly electronic conductor, and therefore mixed with 8 YSZ for ionic conduction in 50:50 weight ratios for the fabrication of symmetrical cell and testing. LSCM73+8YSZ paste was prepared using ink vehicle (Fuel Cell Materials). LSCM73+8YSZ working and counter electrodes (thickness: $\sim 20 \mu \mathrm{m}$, diameter: $10 \mathrm{~mm}$ ) were screen-printed on both sides of $200 \mu \mathrm{m}$ thick $\left(\mathrm{ZrO}_{2}\right)_{0.92}\left(\mathrm{Y}_{2} \mathrm{O}_{3}\right)_{0.08}$ (YSZ) electrolyte (Fuel Cell Materials). After drying at room temperature, the electrodes were sintered at $1200^{\circ} \mathrm{C}$ (heating rate of $3^{\circ} \mathrm{C} / \mathrm{min}$ ) for $2 \mathrm{~h}$ in air. Lower sintering temperature $\left(1200^{\circ} \mathrm{C}\right)$ was chosen for fabrication of the cell to obtain porous electrode layer as well as to avoid secondary phase's formation that were observed at $1400^{\circ} \mathrm{C}$. No secondary phases are identified in the as-sintered symmetrical cells. Platinum screen current collector (Alfa Aesar, 50 mesh) and platinum wires (Alfa Aesar, $0.25 \mathrm{~mm}$ ) were attached to each electrode using platinum paste (Electro-Science Laboratories Inc.). The platinum paste was cured in air at $900^{\circ} \mathrm{C}$ for $1 \mathrm{~h}\left(3^{\circ} \mathrm{C} / \mathrm{min}\right)$. The electrochemical active area of the cell electrode 
was calculated to be $0.8 \mathrm{~cm}^{2}$. As-assembled symmetric cells of configuration LSCM73+8YSZ //8YSZ//LSCM73+8YSZ were installed in a tubular alumina reaction chamber placed in the constant temperature zone of a furnace. The leads from a multi-channel potentiostat (VMP2, Bio-Logic) were attached to the assembled symmetric cell.

\subsection{Electrochemical testing}

The symmetrical cells were heated to $950^{\circ} \mathrm{C}\left(3^{\circ} \mathrm{C} / \mathrm{min}\right)$ in flowing air and $\mathrm{Ar}-3 \% \mathrm{H}_{2}-3 \% \mathrm{H}_{2} \mathrm{O}$ with flow rate maintained at $300 \mathrm{sccm} .3 \%$ water vapor was introduced in the $\mathrm{Ar}-3 \% \mathrm{H}_{2}$ gas stream through a water bubbler at room temperature. Using the potentiostat, a pre-determined constant bias of $0.5 \mathrm{~V}$ was applied for $80 \mathrm{~h}$. The impedance was measured (at four hour intervals) in the frequency range from $100 \mathrm{mHz}$ to $200 \mathrm{kHz}$ using a $10 \mathrm{mV}$ alternating current. To ensure reproducibility, experiments were repeated several times at the imposed voltage condition. Posttest characterization of the symmetrical cells was performed using SEM-EDS (FEI - ESEM Quanta 250).

\section{Results and Discussion:}

\subsection{Crystal structure}

Fig. 2 shows the XRD pattern of LSCM73 bisque-fired at $1100^{\circ} \mathrm{C}$ in air and sintered at $1400^{\circ} \mathrm{C}$ in air, $\mathrm{N}_{2}$, and $\mathrm{Ar}-3 \% \mathrm{H}_{2}-3 \% \mathrm{H}_{2} \mathrm{O}$ atmosphere. Extra peaks corresponding to the $\mathrm{SrCrO}_{4}$ (JCPDS 073-1082) are identified in the bisque-fired sample in agreement with SrO$\mathrm{Cr}_{2} \mathrm{O}_{3}-\mathrm{La}_{2} \mathrm{O}_{3}$ phase diagram [39]. The width of the peaks appears to increase likely due to the diminution of the perovskite grain size with decreasing in the $\mathrm{PO}_{2}$ as is indicated in the next section 3.2. The crystal structure for LSCM73 is rhombohedral (JCPDS 75-9872). However, 
the peaks splitting corresponding to the rhombohedral phase decreases with decrease in $\mathrm{PO}_{2}$. And, it almost disappears in case of the samples sintered in $\mathrm{Ar}-3 \% \mathrm{H}_{2}-3 \% \mathrm{H}_{2} \mathrm{O}$ attributing to less distortion of the lattice and higher symmetry phase formation. The possible higher symmetry phase is cubic (JCPDS 074-1961) after rhombohedral [36]. This is consistent with the co-existence of cubic and rhombohedral phase for LSCM73 when sintered in $\mathrm{N}_{2}$. But, in Ar- $3 \% \mathrm{H}_{2}-3 \% \mathrm{H}_{2} \mathrm{O}$, predominantly cubic phase is identified corresponding to disappearance of the peaks splitting and phase transformation to the higher symmetry phase. In future, a detailed study will be investigated for in-depth understanding of the phase transformation as a function of $\mathrm{PO}_{2}$.

In case of air and $\mathrm{N}_{2}$ atmosphere, new peaks are identified as $\mathrm{Mn}-\mathrm{Cr}-\mathrm{O}$ spinel phase (marked by blue five pointed star) i.e. $\mathrm{MnCr}_{2} \mathrm{O}_{4}$ (JCPDS 075-1614) as shown in Fig. 2. The peaks disappearance corresponding to $\mathrm{MnCr}_{2} \mathrm{O}_{4}$ is observed for the samples sintered in Ar$3 \% \mathrm{H}_{2}-3 \% \mathrm{H}_{2} \mathrm{O}$ atmosphere. However, presence of new peaks (marked by green four pointed star) is observed for the samples sintered in lower oxygen partial pressure $\left(\mathrm{N}_{2}\right.$ and $\mathrm{Ar}-3 \% \mathrm{H}_{2}-$ $3 \% \mathrm{H}_{2} \mathrm{O}$ ). The peaks are identified as $\mathrm{Mn}_{3} \mathrm{O}_{4}$ (JCPDS 086-2337) in reducing gas atmospheres

$[36,40]$. Co-existence of $\mathrm{MnCr}_{2} \mathrm{O}_{4}$ and $\mathrm{Mn}_{3} \mathrm{O}_{4}$ is observed for the samples sintered in $\mathrm{N}_{2}\left(\sim 10^{-5}\right.$ atm) atmosphere. However, in $\mathrm{Ar}-3 \% \mathrm{H}_{2}-3 \% \mathrm{H}_{2} \mathrm{O}$ atmosphere, only $\mathrm{Mn}_{3} \mathrm{O}_{4}$ peaks are identified.

\subsection{Sintering behavior and microstructural analysis}

Fig. 3 shows the density of LSCM73 as a function of oxygen partial pressure $\left(\mathrm{PO}_{2}\right)$ sintered at $1400^{\circ} \mathrm{C}$ for $10 \mathrm{~h}$. The density of bisque fired sample is $\sim 48 \%$ which increases to $\sim 68 \%$ for air sintered sample. However, it decreases to $\sim 56 \%$ with decrease in $\mathrm{PO}_{2}$ for the sample sintered in $\mathrm{Ar}-3 \% \mathrm{H}_{2}-3 \% \mathrm{H}_{2} \mathrm{O}$. Also, the average grain size decreases from $3.0 \mu \mathrm{m}$ (air) 
to $1.2 \mu \mathrm{m}\left(\mathrm{N}_{2}\right)$ to $0.6 \mu \mathrm{m}\left(\mathrm{Ar}-3 \% \mathrm{H}_{2}-3 \% \mathrm{H}_{2} \mathrm{O}\right)$ with decrease in $\mathrm{PO}_{2}$. Fig. 4 shows the polished surface SEM microstructures of the samples sintered in air, $\mathrm{N}_{2}\left(\sim 10^{-5} \mathrm{~atm}\right)$ and $\mathrm{Ar}-3 \% \mathrm{H}_{2^{-}}$ $3 \% \mathrm{H}_{2} \mathrm{O}\left(\sim 10^{-10} \mathrm{~atm}\right)$ gas atmosphere. In oxidizing atmosphere (air), secondary phases have been observed predominantly at grain boundaries as marked in Fig. 4a. Elemental analysis reveals that the secondary phases mainly consist of $\mathrm{Mn}$ and $\mathrm{Cr}$ with small amount of $\mathrm{La}$ and $\mathrm{Sr}$ as shown in Table 1. Fig. 5 shows the elemental mapping of air sintered sample with enriched $\mathrm{Mn}$ and $\mathrm{Cr}$ phases. These phases are $\mathrm{MnCr}_{2} \mathrm{O}_{4}$ spinel as confirmed from XRD. The spinel formation decreases with decrease in $\mathrm{PO}_{2}$. However, a new Mn-rich phase is observed in the samples sintered in reducing atmosphere, and it increases with decreasing oxygen partial pressure as shown in Fig 4b and 4c. This is also observed in the elemental mapping (Fig. 6) of LSCM73 sintered in $\mathrm{Ar}-3 \% \mathrm{H}_{2}-3 \% \mathrm{H}_{2} \mathrm{O}$. Table 2 shows the SEM-EDS elemental analysis of Mn-rich phase and bulk. The phase is identified as $\mathrm{Mn}_{3} \mathrm{O}_{4}$ using XRD in Fig 2.

It is known that densification of $\mathrm{Sr}$-doped $\mathrm{LaCrO}_{3}$ is assisted by liquid phase $\left(\mathrm{SrCrO}_{4}\right)$ sintering [41]. The reaction (1) is favored at an oxygen partial pressure of $0.21 \mathrm{~atm}$.

$$
\mathrm{SrO}(\mathrm{s})+1 / 2 \mathrm{Cr}_{2} \mathrm{O}_{3}(\mathrm{~s})+3 / 4 \mathrm{O}_{2} \leftrightarrow \mathrm{SrCrO}_{4}(\mathrm{~s})
$$

Gibb's free energy formation for $\mathrm{SrCrO}_{4}$ are -158 and $-50 \mathrm{~kJ} \mathrm{~mol}^{-1}$ at $\mathrm{PO}_{2} \sim 0.21$ and $10^{-5}$ atm $\left(900^{\circ} \mathrm{C}\right)$ respectively. With decreasing oxygen partial pressure, the Gibb's free energy for the formation of $\mathrm{SrCrO}_{4}$ increases, and becomes positive at $900^{\circ} \mathrm{C}$ for the partial pressures less than $10^{-7.2} \mathrm{~atm}$. For example, the free energy for $\mathrm{SrCrO}_{4}$ formation is $+75 \mathrm{~kJ} \mathrm{~mol}^{-1}$ at $\sim 10^{-10}$ atm $900^{\circ} \mathrm{C}$ [42]. In addition, according to $\mathrm{SrO}-\mathrm{Cr}_{2} \mathrm{O}_{3}-\mathrm{La}_{2} \mathrm{O}_{3}$ system, $\mathrm{SrCrO}_{4}$ phase is unstable at low oxygen partial pressure $\left(\sim 10^{-9} \mathrm{~atm}\right)$ at $1600^{\circ} \mathrm{C}[39]$.

In case of $\mathrm{A}$-site doped $\mathrm{La}_{0.7} \mathrm{Sr}_{0.3} \mathrm{CrO}_{3}, \mathrm{SrCrO}_{4}$ phase exolution occurs at $\sim 800^{\circ} \mathrm{C}$ and melts at $1256^{\circ} \mathrm{C}$ [43]. The $\mathrm{SrCrO}_{4}$ liquid phase re-dissolves into the perovskite at high 
temperature and assists densification. Similarly, in case of A and B-site doped LSCM73, the $\mathrm{SrCrO}_{4}$, which is present in the bisque fired sample liquefies and re-dissolves into the lattice at high temperature resulting in higher densification. Higher grain growth is also achieved for the samples sintered in air due to the liquid phase assisted sintering. However, the grain growth and density decrease on lowering $\mathrm{PO}_{2}$. Lower densification with decreasing oxygen partial pressure is associated with decreasing $\mathrm{SrCrO}_{4}$ and subsequent liquid phase sintering. To validate our hypothesis, $0.5 \%$ of $\mathrm{SrCrO}_{4}$ is added to $\mathrm{LSCM}_{3}$ and sintered in air under same conditions. The

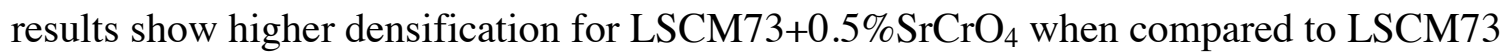
sintered sample as shown in Fig. 3. The SEM micrograph of the sintered $\mathrm{LSCM} 3+0.5 \% \mathrm{SrCrO}_{4}$ sample is shown in Fig. 4d. Highest density $(\sim 73 \%)$ is achieved for LSCM73 when mixed with $0.5 \% \mathrm{SrCrO}_{4}$ and sintered in air. This corresponds to the higher amount of liquid phase formation [44].

On the other hand, chromium evaporation is likely to occur for lanthanum chromite based materials in the form of $\mathrm{CrO}_{3}$ and it condenses as $\mathrm{Cr}_{2} \mathrm{O}_{3}$ (Eq. 2) at the grain boundaries (irregular contacts) due to the surface energetics [13].

$$
4 \mathrm{CrO}_{3} \rightarrow 2 \mathrm{Cr}_{2} \mathrm{O}_{3}+3 \mathrm{O}_{2}
$$

Manganese is soluble in $\mathrm{Cr}_{2} \mathrm{O}_{3}$ up to a limit of $1.6 \%$ of the cation sites at $1000^{\circ} \mathrm{C}$ [45]. Manganese tends to diffuse and react with $\mathrm{Cr}_{2} \mathrm{O}_{3}$ to form $\mathrm{MnCr}_{2} \mathrm{O}_{4}$ (Eq. 3), preferentially at the grain boundaries of LSCM73 as shown in Fig. 4a and d. Thermodynamically, the spinel phase formation is favorable at $1400^{\circ} \mathrm{C}$ with the Gibbs free energy of formation for $\mathrm{MnCr}_{2} \mathrm{O}_{4}$ to be $40.1 \mathrm{~kJ} / \mathrm{mol}[46]$.

$$
\mathrm{MnO}+\mathrm{Cr}_{2} \mathrm{O}_{3} \rightarrow \mathrm{MnCr}_{2} \mathrm{O}_{4}
$$


The formation of spinel phase is also in agreement with Mn-Cr-O phase diagram [36]. According to the phase diagram, the cubic spinel phase forms at $1400^{\circ} \mathrm{C}$ in air. With decrease in $\mathrm{PO}_{2}$, the Cr-evaporation and condensation with the formation of $\mathrm{Cr}_{2} \mathrm{O}_{3}$ decreases. Subsequently, the formation of $\mathrm{MnCr}_{2} \mathrm{O}_{4}$ also decreases with decrease in oxygen partial pressure. This is in agreement with our observation in the SEM micrographs of LSCM73 in air (Fig. 4a), $\mathrm{N}_{2}$ (Fig. 5b) and $\mathrm{Ar}-3 \% \mathrm{H}_{2}-3 \% \mathrm{H}_{2} \mathrm{O}$ (Fig. 4c). On the other hand, $\mathrm{Mn}_{3} \mathrm{O}_{4}$ phase is observed in the samples sintered in $\mathrm{N}_{2}\left(\sim 10^{-5} \mathrm{~atm}\right)$ and $\mathrm{Ar}-3 \% \mathrm{H}_{2}-3 \% \mathrm{H}_{2} \mathrm{O}\left(\sim 10^{-10} \mathrm{~atm}\right)$ gas atmosphere. However, the formation of $\mathrm{Mn}_{3} \mathrm{O}_{4}$ increases with decrease in $\mathrm{PO}_{2}$. In the literature, it is given that $\mathrm{MnCr}_{2} \mathrm{O}_{4}$ dissociates into $\mathrm{MnO}$ in reducing gas atmosphere [35-36]. However, no experimental or theoretical evidence is provided. Furthermore, if the spinel phase dissociates into $\mathrm{MnO}$ and $\mathrm{Cr}_{2} \mathrm{O}_{3}$ in reducing atmosphere, the appearance of $\mathrm{Cr}_{2} \mathrm{O}_{3}$ should be detected like $\mathrm{MnO}$ using XRD or SEM. The presence of $\mathrm{Cr}_{2} \mathrm{O}_{3}$ is not identified in the literature as well as in our study. The formation of $\mathrm{MnCr}_{2} \mathrm{O}_{4}$ is dependent on $\mathrm{Cr}_{2} \mathrm{O}_{3}$ (Eq. 3). According to our study, in reducing atmosphere, we propose that $\mathrm{Mn}$ diffuses into the condensed $\mathrm{Cr}_{2} \mathrm{O}_{3}$ until it is consumed to form $\mathrm{MnCr}_{2} \mathrm{O}_{4}$. Afterwards, $\mathrm{Mn}$ diffuses at the outer surface and exits in the lattice as $\mathrm{MnO}$. During cooling, the temperature and $\mathrm{PO}_{2}$ decreases to the region where $\mathrm{MnO}$ is not stable and it forms $\mathrm{Mn}_{3} \mathrm{O}_{4}$ in agreement with our XRD results [40].

The exolution of MnO phase in LSCM73 in reducing gas atmosphere can also be explained based on the oxygen exchange defect reactions. It is known that Mn can exist in three valence states i.e. $\mathrm{Mn}^{2+} / \mathrm{Mn}^{3+} / \mathrm{Mn}^{4+}$ in LSCM [34]. Due to the existence of disproportionate $\mathrm{Mn}$ valence state, oxygen vacancies exist in the lattice of LSCM73 for the charge compensation. At lower $\mathrm{PO}_{2}$, the transition of $\mathrm{Mn}^{4+} \rightarrow \mathrm{Mn}^{3+}$ and $\mathrm{Mn}^{3+} \rightarrow \mathrm{Mn}^{2+}$ results in higher amount of oxygen 
vacancies formation for charge neutrality. The oxygen exchange between LSCM73 and gas phase can be represented as shown below [34]:

$\frac{1}{2} \mathrm{O}_{2}+\mathrm{V}_{\mathrm{O}}^{\ddot{*}}+2 \mathrm{Mn}_{\mathrm{Mn}}^{\times}=\mathrm{O}_{\mathrm{O}}^{\times}+2 \mathrm{Mn}_{\mathrm{Mn}}^{\cdot}$

$\frac{1}{2} \mathrm{O}_{2}+\mathrm{V}_{\mathrm{O}}^{*}+2 \mathrm{Mn}_{\mathrm{Mn}}^{\prime}=\mathrm{O}_{\mathrm{O}}^{\times}+2 \mathrm{Mn}_{\mathrm{Mn}}^{\times}$

where $\mathrm{Mn}_{\mathrm{Mn}}^{\times}$refers to $\mathrm{Mn}^{3+}$ on $\mathrm{Mn}^{3+}$ sites, $\mathrm{Mn}_{\mathrm{Mn}}$ refers to $\mathrm{Mn}^{4+}$ on $\mathrm{Mn}^{3+}$ sites, $\mathrm{Mn}_{\mathrm{Mn}}^{\prime}$ refers to $\mathrm{Mn}^{2+}$ on $\mathrm{Mn}^{3+}$ sites, and $\mathrm{V}_{\mathrm{O}}$ refers to oxygen vacancy with two positive charges.

We postulate that LSCM73 perovskite lattice structure destabilizes due to the existence of higher amount of oxygen vacancies and $\mathrm{Mn}^{2+}(0.830 \AA)$ with higher ionic radii than $\mathrm{Mn}^{3+}$ $(0.645 \AA)$. Therefore, in reducing atmosphere, $\mathrm{Mn}^{2+}$ does not retain in the $\mathrm{A}^{3+} \mathrm{B}^{3+} \mathrm{O}_{3}^{2-}$ perovskite lattice of LSCM73 and exolve as MnO. Oishi et al. [34] have reported similar exolution of MnO from LSCM55 lattice when exposed to $\mathrm{PO}_{2} \sim 10^{-20}$ atm at $900^{\circ} \mathrm{C}$.

Mechanism and the sintering behavior of LSCM73 in air, $\mathrm{N}_{2}$ and $\mathrm{Ar}-3 \% \mathrm{H}_{2}-3 \% \mathrm{H}_{2} \mathrm{O}$ gas atmosphere are shown in Fig. 7. In step 1, the starting material is same for the three cases i.e. bisque fired (at $1100^{\circ} \mathrm{C}$ ) $\mathrm{LSCM} 73$ with the existence of $\mathrm{SrCrO}_{4}$ (indicated by yellow color). In step 2, the $\mathrm{SrCrO}_{4}$ melts (indicated by yellow color) at $\sim 1256^{\circ} \mathrm{C}$ in case of air and $\mathrm{N}_{2}$ atmosphere. However, due to the positive Gibbs free energy of formation in reducing atmosphere, $\mathrm{SrCrO}_{4}$ is unstable for the samples sintered in $\mathrm{Ar}-3 \% \mathrm{H}_{2}-3 \% \mathrm{H}_{2} \mathrm{O}\left(\sim 10^{-10} \mathrm{~atm}\right)$. It is hypothesized that the $\mathrm{SrCrO}_{4}$ would dissociate into $\mathrm{SrO}$ and $\mathrm{Cr}_{2} \mathrm{O}_{3}$ and dissolve back into the lattice when heating up to the sintering temperature. During Step 3, the evaporated $\mathrm{CrO}_{3}$ condenses and deposits in the form of $\mathrm{Cr}_{2} \mathrm{O}_{3}$ (indicated by green color), preferentially at the grain boundaries due to higher surface energy. And, Mn diffuses at the outer surface and reacts with $\mathrm{Cr}_{2} \mathrm{O}_{3}$ to form $\mathrm{MnCr}_{2} \mathrm{O}_{4}$ spinel (indicated by red color). However, as explained above, the $\mathrm{CrO}_{3}$ evaporation and condensation as $\mathrm{Cr}_{2} \mathrm{O}_{3}$ decreases (step 3) in reducing atmosphere. Therefore, the 
availability of $\mathrm{Cr}_{2} \mathrm{O}_{3}$ to react with $\mathrm{Mn}$ to form $\mathrm{MnCr}_{2} \mathrm{O}_{4}$ decreases with decrease in $\mathrm{PO}_{2}$.

Consequently, Mn diffuses at the outer surface and exists as $\mathrm{Mn}_{3} \mathrm{O}_{4}$ in the lattice. As a result, both $\mathrm{MnCr}_{2} \mathrm{O}_{4}$ and $\mathrm{Mn}_{3} \mathrm{O}_{4}$ exist for the sample sintered in $\mathrm{N}_{2}$ atmosphere as shown in the step 4 . In $\mathrm{Ar}-3 \% \mathrm{H}_{2}-3 \% \mathrm{H}_{2} \mathrm{O}$ atmosphere with least $\mathrm{PO}_{2}\left(\sim 10^{-10}\right.$ atm $)$ among the three cases, there is no $\mathrm{MnCr}_{2} \mathrm{O}_{4}$ formation due to the absence of $\mathrm{Cr}_{2} \mathrm{O}_{3}$ (step 3) and therefore, Mn comes out as $\mathrm{Mn}_{3} \mathrm{O}_{4}$ (indicated by orange color) in step 4.

\subsection{Thermodynamic calculations:}

To support our experimental results and hypothesis on the sintering behavior of LSCM73, we performed thermodynamic calculations using the CALculation of PHAse Diagram (CALPHAD). The CALPHAD approach was pioneered by Kaufman [47] to model complex phase equilibria in multicomponent systems. Its theoretical basis is thermodynamic description of individual phases. The thermodynamic database was developed using Thermo-Calc [48]. Thermo-Calc is a program developed by KTH Royal Institute of Technology in the 1970s. For over 40 years, Thermo-Calc has been at the forefront of scientific software and databases for calculations involving computational thermodynamics $[47,49]$.

The customized thermodynamic database for La-Sr-Cr-Mn-O-H-S system was adopted in the current investigations, which is able to simulate the phase equilibria of perovskite at various gas conditions including the gas species like $\mathrm{H}_{2} \mathrm{O}, \mathrm{O}_{2}, \mathrm{SO}_{2}, \mathrm{H}_{2} \mathrm{~S}$, etc. It is a combined database with the La-Sr-Cr-Mn-O database [46,50-51] and SSUB database [52]. It has the Gibbs energy description of all the phases we are interested in the current work, including the perovskite and spinel phases. It is expanded by adding $\mathrm{Cr}$ on the basis of the La-Sr-Mn-O thermodynamic database, which was initially developed to consider the Cr poisoning effect to LSM. 
In the current work, the phase stabilities of LSCM73 were examined at different oxygen partial pressures at $1400^{\circ} \mathrm{C}$ in comparison with the experimental observations. According to our thermodynamic calculations and Fig. 8, LSCM73 will form spinel in air, with the decrease of the oxygen partial pressure, phases like $\mathrm{MnO}$ and $\mathrm{SrO}$ will form. The theoretical predictions are in agreement with our experimental results at $1400^{\circ} \mathrm{C}$. Spinel phase co-exists with perovskite phase in air (0.21 atm). However, at lower $\mathrm{PO}_{2}\left(\sim 10^{-5}\right.$ atm), three phase co-exists as shown in our experimental observations i.e. perovskite, spinel and $\mathrm{MnO}$. With further decrease in $\mathrm{PO}_{2}$, only $\mathrm{MnO}$ phase co-exists with perovskite as shown in Fig. 8 which is also in agreement with our experimental results. As mentioned in the previous section, during cooling, it is to be noted that the temperature and $\mathrm{PO}_{2}$ reduces to the region where $\mathrm{MnO}$ is not stable and it forms $\mathrm{Mn}_{3} \mathrm{O}_{4}$ [40]. This is in agreement with our XRD results.

\subsection{Electrochemical measurements and post-test observations}

Fig. 9a and b shows electrochemical performance of the symmetrical cell (LSCM73+8YSZ//8YSZ//LSCM73+8YSZ) at $950^{\circ} \mathrm{C}$ and $0.5 \mathrm{~V}$ in air and $\mathrm{Ar}-3 \% \mathrm{H}_{2}-3 \% \mathrm{H}_{2} \mathrm{O}$ respectively. Ohmic resistance is represented by high frequency intercept, while the semicircle diameter represents sum of the non-ohmic contributions [53]. In case of reducing atmosphere $\left(\mathrm{Ar}-3 \% \mathrm{H}_{2}-3 \% \mathrm{H}_{2} \mathrm{O}\right)$, two semicircles are observed corresponding to the charge (ion) transfer at the electrolyte/electrode interface and electrochemical kinetics involved with electrode material (e.g. adsorption and/or diffusion processes to/from the interface) [54-55]. However, the two electrode arcs merged in oxidizing atmosphere (air) [41]. Fig. 10 shows comparison plot of ohmic and non-ohmic resistances as a function of time for the cell tested at $0.5 \mathrm{~V}$ in air and Ar$3 \% \mathrm{H}_{2}-3 \% \mathrm{H}_{2} \mathrm{O}$. In case of oxidizing atmosphere, ohmic and non-ohmic resistances increase with 
time, but there is no significant variation observed especially after $20 \mathrm{~h}$ as shown in Fig 9a and 10. This corresponds to higher stability of LSCM73 in oxidizing atmosphere. On the other hand, in reducing atmosphere, the ohmic resistance almost stabilizes with increase in time as shown in Fig. 10. However, non-ohmic resistance continuously increases with time. The non-ohmic resistance for the tested cell is $\sim 12.0 \Omega . \mathrm{cm}^{2}(0 \mathrm{~h})$ and increases to $\sim 24.9 \Omega . \mathrm{cm}^{2}$ (80h) in Ar$3 \% \mathrm{H}_{2}-3 \% \mathrm{H}_{2} \mathrm{O}$ at $950^{\circ} \mathrm{C}$ when bias of $0.5 \mathrm{~V}$ is applied. Resistance of the tested cell increases when exposed to reducing gas atmosphere as shown in Fig. 10.

Symmetrical cells (LSCM73+8YSZ//8YSZ//LSCM73+8YSZ) before and after testing are analyzed. No changes are identified with the naked eye. In addition, no delamination of the porous electrode layers is observed after manual removal of Pt mesh along with Pt wires. Bulk electrode and electrode/electrolyte interfaces are examined for microstructural changes and reaction products formation. Fig. 11a shows the interface of LSCM73+8YSZ (anode) and 8YSZ (electrolyte). There is no interface layer or compound formation observed at the interface in air. Furthermore, when compared to as-sintered cell (Fig. 11b), no changes are identified in the microstructure of the tested cell in air (Fig. 11c). However, in $\mathrm{Ar}-3 \% \mathrm{H}_{2}-3 \% \mathrm{H}_{2} \mathrm{O}$, surface morphology of LSCM73 phase is significantly modified as shown in Fig. 11d. Nano-size particles segregation is observed on the anode surface of the tested cell as shown in Fig. 11d. Surface compositional analysis is performed using SEM-EDS at $\sim 20$ different points. It is observed that the average Sr: La ratio is higher for the symmetrical cell tested in $\mathrm{Ar}-3 \% \mathrm{H}_{2-}$ $3 \% \mathrm{H}_{2} \mathrm{O}(\mathrm{Sr}: \mathrm{La} \sim 0.65 \pm 0.05)$ when compared to those tested air $(\mathrm{Sr}: \mathrm{La} \sim 0.44 \pm 0.05)$ which matches with as-sintered cell ( $\mathrm{Sr}: \mathrm{La} \sim 0.43 \pm 0.04)$. This corresponds to the $\mathrm{Sr}$-segregation in case of the cell tested in reducing atmosphere. Sr enrichment on lanthanum strontium manganite surface is reported earlier after heat treatment $\left(1000^{\circ} \mathrm{C}\right)$ in nitrogen atmosphere (humid) at low 
partial pressure of oxygen [56]. Hu et al. [50] have observed similar surface morphological changes attributing to Sr-segregation in $\left(\mathrm{La}_{0.8} \mathrm{Sr}_{0.2}\right)_{0.98} \mathrm{MnO}_{3}$ (LSM) after electrochemical cell testing in air (with $50 \%$ water vapor) at $850^{\circ} \mathrm{C}$ for $100 \mathrm{~h}$. Consequently, the resistance of the LSM based symmetrical cells increased [57]. Similarly, it is postulated that the $\mathrm{SrO}$ segregation on LSCM73 surface results in the increase of resistance with time when tested in $\mathrm{Ar}-3 \% \mathrm{H}_{2-}$ $3 \% \mathrm{H}_{2} \mathrm{O}$. Figure $12 \mathrm{a}$ and $\mathrm{b}$ shows electrode-electrolyte interface after removable of LSCM73 layer from the cells tested in air and $\mathrm{Ar}-3 \% \mathrm{H}_{2}-3 \% \mathrm{H}_{2} \mathrm{O}$ respectively. Ridges and lip formations along with the reaction zone (indicated by yellow circles) are observed at the contact of $\mathrm{LSCM} / 8 \mathrm{YSZ}$ and attributes to an interaction between electrode and electrolyte in $\mathrm{Ar}-3 \% \mathrm{H}_{2-}$ $3 \% \mathrm{H}_{2} \mathrm{O}$ unlike air. Similar interactions are reported between LSM/8YSZ by Keane [58] and Li et al. [59] resulting into an increase in the polarization resistance under the applied bias. However, less interaction is identified in this study for LSCM-8YSZ system when compared to LSM8YSZ.

\section{Conclusion}

$\left(\mathrm{La}_{0.75} \mathrm{Sr}_{0.25}\right)_{0.95} \mathrm{Cr}_{0.7} \mathrm{Mn}_{0.3} \mathrm{O}_{3}$ (LSCM73) experiences enhanced densification in air during sintering at $1400^{\circ} \mathrm{C}$ when compared to reducing atmosphere. Spinel phase formation $\left(\mathrm{MnCr}_{2} \mathrm{O}_{4}\right)$ has been observed when sintered in air $(0.21 \mathrm{~atm})$ and $\mathrm{N}_{2}\left(\sim 10^{-5} \mathrm{~atm}\right)$ whereas $\mathrm{Mn}_{3} \mathrm{O}_{4}$ phase

formation is observed at lower oxygen partial pressure $\left(\sim 10^{-5}\right.$ and $\left.\sim 10^{-10} \mathrm{~atm}\right)$. Thermodynamic calculations as well as construction of phase diagram, developed using Thermo-Calc software, supports experimental observations. The crystal structure of the sintered LSCM73 shows rhombohedral lattice structure in air and its transformation to cubic in reducing atmosphere. Stable and superior performance of the symmetric cell of configuration 
LSCM73+8YSZ//8YSZ//LSCM73+8YSZ, during electrochemical testing at $950^{\circ} \mathrm{C}$, is attributed to surface and interface stability and lack of Sr segregation in oxidizing atmospheres when compared to exposure to reducing atmospheres.

\section{Acknowledgements}

Authors acknowledge the financial support from the US Department of Energy under contract DE-FC26-07NT43088. Center for Clean Energy Engineering at the University of Connecticut is acknowledged for providing laboratory support and the use of characterization facility. 


\section{References}

[1] Faravelli T, Ranzi E, Candusso C, Frassoldati A, Cuoci A and Tolazzi D. Simplified kinetic schemes for oxy-fuel combustion. 1st International Conference on Sustainable Fossil Fuels for Future Energy, 2009.

[2] Stadler H, Beggel F, Habermehl M, Persigehl B, Kneer R, Modigell M, Jeschke P. Oxyfuel coal combustion by efficient integration of oxygen transport membranes. Int. J. Greenhouse Gas Control 2011;5:7-15

[3] Anderson LL, Armstrong PA, Repasky JM, and Stein VE, "Enabling Clean Coal Power Generation: ITM Oxygen Technology. Proceedings of the 28th Annual International Pittsburgh Coal Conference, Pittsburgh, PA, USA, 2011.

[4] Shin MJ, Yu JH. Phases transition and oxygen permeating properties of SrFeGa0.25O3- $\delta$.

Int. J. Hydrogen. Energy 2010;35:7512-7518.

[5] Mills GA. Liquid Fuels from syngas - progress report. Department of chemical engineering, University of Delaware, Newark 116-117.

[6] Nagabhushana N, Lane JA, Christie GM, Hassel BAV. Composite oxygen ion transport membrane. US Patent 7556676B2, 2009.

[7] Bouwmeester HJM, Burggraaf AJ, in: Burggraaf AJ, Cot L (Eds.). Fundamentals of inorganic membrane science and technology. Membrane Science and Technology Series 4, Elsevier, Amsterdam, 1996, pp. 435-510.

[8] Sfeir J. $\mathrm{LaCrO}_{3}$-based anodes: stability considerations. J. Power Sources 2003;118:276-285.

[9] Atkinson A, Barnett S., Gorte RJ, Irvine JTS, McEvoy AJ, Moguensen M, Singhal SC, Vohs J. Advanced anodes for high-temperature fuel cells. Nat. Mater. 2004;3:17-27. 
[10] Vert VB, Melo FV, Navarrete L, Serra JM. High performance anodes with tailored catalytic properties for $\mathrm{La}_{5.6} \mathrm{WO}_{11.4-\delta}$ based proton conducting fuel cells. Appl. Catal. B: Environ. 2012;115:346-356.

[11] Duran P, Tartaj J, Capel F, Moure C. Formation, sintering and thermal expansion behavior of $\mathrm{Sr}$ - and $\mathrm{Mg}$-doped $\mathrm{LaCrO}_{3}$ as $\mathrm{SOFC}$ interconnector prepared by the ethylene glycol polymerized complex solution synthesis method. J. Eur. Ceram. Soc. 2004;24:2619-2629. [12] Mukasyan AS, Costello C, Sherlock KP, Lafarga D, Varma A. Sep. and Purif. Technol. Perovskite membranes by aqueous combustion synthesis: synthesis and properties. 2001;25:117-126.

[13] Gupta S, Mahapatra MK, Singh P. Phase transformation, thermal expansion and electrical conductivity of lanthanum chromite. Mat. Res. Bull. 2013;48:3262-67.

[14] Jacob KT, Gupta S, Singh P. Thermodynamic properties of $\mathrm{LaCrO}_{4}, \mathrm{La}_{2} \mathrm{CrO}_{6}$ and $\mathrm{La}_{2} \mathrm{Cr}_{3} \mathrm{O}_{12}$, and sub-solidus phase relations in the system lanthanum-chromium-oxygen. J. Am. Ceram. Soc. 2013;96:3933-38.

[15] Jacob KT, Gupta S, Singh P. Electrochemical determination of Gibbs energy of formation of $\mathrm{LaCrO}_{3}$ using a composition- graded bi-electrolyte. J. Am. Ceram. Soc. 2013;96:3272-3278. [16] Gupta S, Mahapatra MK, Singh P. Lanthanum chromite based perovskites for oxygen transport membrane. MSE: R: Reports 2015;90:1-36.

[17] Kharton VV, Tsipis EV, Marozau IP, Viskup AP, Frade JR, Irvine JTS. Mixed conductivity and electrochemical behavior of $\left(\mathrm{La}_{0.75} \mathrm{Sr}_{0.25}\right)_{0.95} \mathrm{Cr}_{0.5} \mathrm{Mn}_{0.5} \mathrm{O}_{3-\delta}$. Solid State Ionics 2007;178:101-113.

[18] Gupta S, Singh P. Manganese doped lanthanum strontium chromite fuel electrode for solid oxide fuel cell and oxygen transport membrane systems. ECS Transactions 2015;66:117-123. 
[19] Kolotygin VA, Tsipis EV, Shaula AL, Naumovich EN, Frade JR, Bredikhin SI, Kharton VV. Transport and electrode properties of perovskite-type $\left(\mathrm{La}_{0.75} \mathrm{Sr}_{0.25}\right)_{0.95} \mathrm{Mn}_{0.5} \mathrm{Cr}_{0.5} \mathrm{Ti}_{\mathrm{x}} \mathrm{O}_{3-\mathrm{d}}(\mathrm{x}=0$ - 0.5). J. Solid State Electrochem. 2011;15:313-327.

[20] Liu JJ, Liu T, Wang WD, Gao JF, Chen CS, $\mathrm{Zr}_{0.84} \mathrm{Y}_{0.16} \mathrm{O}_{1.92}-\mathrm{La}_{0.8} \mathrm{Sr}_{0.2} \mathrm{Cr}_{0.5} \mathrm{Fe}_{0.5} \mathrm{O}_{3-\delta}$ dualphase composite hollow fiber membrane targeting chemical reactor applications. J. Mem. Sci. 2012;389:435-440.

[21] Wenyi T, Qin Z, Han Y, Xiufang Z, Hongyi Li. Deactivation of anode catalyst $\mathrm{La}_{0.75} \mathrm{Sr}_{0.25} \mathrm{Cr}_{0.5} \mathrm{Mn}_{0.5} \mathrm{O}_{3 \pm \delta}$ in $\mathrm{SOFC}$ with fuel containing hydrogen sulfur: The role of lattice oxygen. Int. J. Hydrogen Energy 2012;37:7398-7404.

[22] He W, Huang H, Chen M, Gao JF, Chen CS. Stability and oxygen transport property of $\mathrm{La}_{0.8} \mathrm{Sr}_{0.2} \mathrm{Cr}_{0.5} \mathrm{Fe}_{0.5} \mathrm{O}_{3-\delta}$, Solid State Ionics 2014;260:86-89.

[23] Tan W, Zhong Q, Xu D, Yan H, Zhu X. Catalytic activity and sulfur tolerance for Mnsubstituted $\mathrm{La}_{0.75} \mathrm{Sr}_{0.25} \mathrm{CrO}_{3 \pm \delta}$ in gas containing $\mathrm{H}_{2} \mathrm{~S}$. Int. J. Hydrogen Energy 2013;36:1665616664.

[24] Fang W, Zhang Y, Gao J, Chen C. Oxygen permeability of asymmetric membrane of functional $\mathrm{La}_{0.8} \mathrm{Sr}_{0.2} \mathrm{Cr}_{0.5} \mathrm{Fe}_{0.5} \mathrm{O}_{3-\delta}(\mathrm{LSCrF})-\mathrm{Zr}_{0.8} \mathrm{Y}_{0.2} \mathrm{O}_{2-\delta}(\mathrm{YSZ})$ supported on porous YSZ. Ceramics International 2014;40:799-803.

[25] Christie GM, Wilson JR, Hassel BAV. Catalyst containing oxygen transport membrane. US Patent 090645A2, 2011.

[26] Nagabhushana N, Lane JA, Christie GM, Hassel BAV. Composite for oxygen ion transport membrane. EP 2054355B1, 2012. 
[27] Van den Bossche M, Matthews R, Lichtenberger A, McIntosh S. Insights into the fuel oxidation mechanism of $\mathrm{La}_{0.75} \mathrm{Sr}_{0.25} \mathrm{Cr}_{0.5} \mathrm{Mn}_{0.5} \mathrm{O}_{3-\mathrm{d}} \mathrm{SOFC}$ anodes. J. Electrochem. Soc. 2010;157:B392-B399.

[28] Nakamura T, Petzow G, Gauckler L. Stability of the perovskite phase $\mathrm{LaBO}_{3}(\mathrm{~B}=\mathrm{V}, \mathrm{Cr}$, $\mathrm{Mn}, \mathrm{Fe}, \mathrm{Co}, \mathrm{Ni}$ ) in reducing atmosphere I. Experimental results. Mater. Res. Bull. 1979;14:649659.

[29] Tao S, Irvine JTS. Synthesis and Characterization of $\left(\mathrm{La}_{0.75} \mathrm{Sr}_{0.25}\right) \mathrm{Cr}_{0.5} \mathrm{Mn}_{0.5} \mathrm{O}_{3}-\mathrm{A}$ RedoxStable, Efficient Perovskite Anode for SOFCs. J. Electrochem. Soc. 2004;151:A252-259.

[30] Tao S, Irvine JTS. A redox-stable efficient anode for solid-oxide fuel cells. Nature Materials 2003;2:320-323.

[31] Filal M, Petot C, Mokchah M, Chateau C, Carpentier JL. "Ionic-conductivity of yittriumdoped zirconia and the composite effect. Solid State Ionics 1995;80:27-35.

[32] Yokokawa H, Sakai N, Kawada T, Dokiya M. Chemical Thermodynamic

Considerations in Sintering of $\mathrm{LaCrO}_{3}$-Based Perovskites. J. Electrochem. Soc. 1991;138:101827.

[33] Masashi M, Yamamoto T, Ichikawa T, Takeda T. Dense sintered conditions and sintering mechanisms for alkaline earth metal $(\mathrm{Mg}, \mathrm{Ca}$ and $\mathrm{Sr})$-doped $\mathrm{LaCrO}_{3}$ perovskites under reducing atmosphere. Solid State Ionics 2002;148:93-101.

[34] Oishi M, Yashiro K, Sato K, Mizusaki J, Kawada T. Oxygen nonstoichiometry and defect structure analysis of B-site mixed perovskite-type oxide $(\mathrm{La}, \mathrm{Sr})(\mathrm{Cr}, \mathrm{M}) \mathrm{O}_{3}$-delta $(\mathrm{M}=\mathrm{Ti}, \mathrm{Mn}$ and Fe). J. Solid State Chem. 2008;181:3177-3184.

[35] Tao S, Irvine JTS. Phase transition in perovskite oxide $\mathrm{La}_{0.75} \mathrm{Sr}_{0.25} \mathrm{Cr}_{0.5} \mathrm{Mn}_{0.5} \mathrm{O}_{3-\delta}$ observed by in situ high temperature neutron powder diffraction. Chem. Mater. 2006;18:5453-5460. 
[36] Jung IH. Critical evaluation and thermodynamic modeling of the $\mathrm{Mn}-\mathrm{Cr}-\mathrm{O}$ system for the oxidation of SOFC interconnect. Solid State Ionics 2006;177:765-777.

[37] Lee W, Cai Z, and Yildiz B. Role of Chemical Heterogeneities on Oxygen Reduction Kinetics on the Surface of Thin Film Cathodes. Ionic and Mixed Conducting Ceramics 8, 2012;45:405-412.

[38] Leng YJ, Chan SH, Khor KA, Jiang SP. Development of LSM/YSZ composite cathode for anode-supported solid oxide fuel cells, Journal of applied electrochemistry 2004;34:409-415. [39] Peck DH, Miller M, Hilpert K. Phase diagram studies in the $\mathrm{SrO}-\mathrm{Cr}_{2} \mathrm{O}_{3}-\mathrm{La}_{2} \mathrm{O}_{3}$ system in air and under low oxygen pressure. Solid state Ionics 1999;123:59-65.

[40] Fritsch S, Navrotsky A. Thermodynamic Properties of Manganese Oxides. J. Am. Cer. Soc. 1996;79:1761-68.

[41] Mori M, Hiei Y, Sammes NM. Sintering behavior and mechanism of Sr-doped lanthanum chromites with A site excess composition in air. Solid State Ionics 1999;123:103-111.

[42] Zhang T, Brow RK, Fahrenholtz WG, Reis ST. Chromate formation at the interface between a solid oxide fuel cell sealing glass and interconnect alloy. J. Power Sources 2012;205:301-306. [43] Simner S, Hardy J, Stevenson J, Armstrong T. Sintering mechanisms in strontium doped lanthanum chromite. J. Mater. Sci. 1999;34:5721-32.

[44] German RM, Farooq S, Kipphut CM. Kinetics of Liquid Phase Sintering. Mater. Sci. Eng. A $1988 ; 215: 215-224$.

[45] Young DJ. High Temperature Oxidation and Corrosion of Metals, Tech. \& Eng. 2008:350351.

[46] Povoden-Karadeniz E. Thermodynamic Database of the La-Sr-Mn-Cr-O Oxide System and 
Applications to Solid Oxide Fuel Cells, Diss., Eidgenössische Technische Hochschule ETH Zürich, Nr. 18139, 2008.

[47] Kaufman L, Bernstein H. Computer Calculation of Phase Diagrams with Special

Reference to Refractory Metals. New York: Academic Press, 1970.

[48] Andersson JO, Helander T, Hoglund LH, Shi PF and Sundman B. THERMO-CALC \&

DICTRA, computational tools for materials science. CALPHAD 2002;26:273-312.

[49] Saunders N, Miodownik AP. CALPHAD (Calculation of Phase Diagrams): A

Comprehensive Guide, Oxford, New York: Pergamon, XVI, 1998:479.

[50] Grundy AN, Hallstedt B, Gauckler LJ. Calphad-Computer Coupling of Phase Diagrams and Thermochemistry 2004;28:191-201.

[51] Povoden-Karadeniz E, Chen M, Ivas T, Grundy AN, Gauckler LJ. Thermodynamic modeling of $\mathrm{La}_{2} \mathrm{O}_{3}-\mathrm{SrO}-\mathrm{Mn}_{2} \mathrm{O}_{3}-\mathrm{Cr}_{2} \mathrm{O}_{3}$ for solid oxide fuel cell applications. J. Mat. Res. 2012;27:1915-1926.

[52] Lehrstuhl für Theoretische Hüttenkunde, Rheinisch-Westfälische Technische Hochschule Aachen, Thermodynamic Properties of Inorganic Materials, Vol. IV, 1999.

[53] Keane M, Mahapatra MK, Verma A, Singh P. LSM-YSZ interactions and anode delamination in solid oxide electrolysis cells. Int. J. Hydrogen Energy 2012;37:16776-16785. [54] Bastidas DM, Tao S, Irvine JTS. A symmetrical solid oxide fuel cell demonstrating redox stable perovskite electrodes. J. Mat. Chem. 2006;16:1603-1605.

[55] Blennowa P, Kent K. Hansen KK, Wallenberg LR, Mogensen M. Effects of Sr/Ti-ratio in $\mathrm{SrTiO}_{3}$-based SOFC anodes investigated by the use of cone-shaped electrodes. Electrochimica Acta 2006;52:1651-1661. 
[56] Knöfel, C, Chen M, Mogensen M. The Effect of Humidity and Oxygen Partial Pressure on LSM-YSZ Cathode. Fuel Cells 2011:669-677.

[57] Hu B, Keane M, Mahapatra MK, Singh P. Stability of strontium-doped lanthanum manganite cathode in humidified air. J. Power Sources 2014;248:196-204.

[58] Keane M, Mahapatra MK, Verma A, Singh P. LSM-YSZ interactions and anode delamination in solid oxide electrolysis cells. Int. J. Hydrogen. Energy 2012;37:16776-16785. [59] Li N, Keane M, Mahapatra MK, Singh P. Mitigation of the delamination of LSM anode in solid oxide electrolysis cells using manganese-modified YSZ. Int. J. Hydrogen. Energy 2013;38:6298-6303. 


\section{Figure Captions}

Fig. 1. Schematic of oxygen transport membrane.

Fig. 2. XRD pattern of LSCM73 bisque-fired $\left(1100^{\circ} \mathrm{C}\right)$ in air and sintered $\left(1400^{\circ} \mathrm{C}\right)$ in air, $\mathrm{N}_{2}$ and $\mathrm{Ar}-3 \% \mathrm{H}_{2}-3 \% \mathrm{H}_{2} \mathrm{O}$.

Fig. 3. Relative density of sintered LSCM73 in air (0.21 atm), $\mathrm{N}_{2}\left(10^{-5}\right.$ atm $)$ and Ar-3\% $\mathrm{H}_{2-}$ $3 \% \mathrm{H}_{2} \mathrm{O}\left(10^{-10} \mathrm{~atm}\right)$.

Fig. 4. Polished surface SEM micrographs of sintered LSCM73 in a) air, b) $\mathrm{N}_{2}$, c) Ar-3\% $\mathrm{H}_{2-}$ $3 \% \mathrm{H}_{2} \mathrm{O}$, and d) air (with $0.5 \% \mathrm{SrCrO}_{4}$ ).

Fig. 5. Elemental mapping of polished surface SEM micrographs of sintered LSCM73 in air. Fig. 6. Elemental mapping of polished surface SEM micrographs of sintered LSCM73 in Ar$3 \% \mathrm{H}_{2}-3 \% \mathrm{H}_{2} \mathrm{O}$ atmosphere.

Fig. 7. Schematic of sintering steps for LSCM73 sintered in air, $\mathrm{N}_{2}$ and $\mathrm{Ar}-3 \% \mathrm{H}_{2}-3 \% \mathrm{H}_{2} \mathrm{O}$.

Fig. 8. Relationship between the phase stabilities of LSCM73 at $1400^{\circ} \mathrm{C}$ and oxygen partial pressure.

Fig. 9. Nyquist plots of impedance spectra obtained from the symmetrical cell of configuration LSCM73+8YSZ//8YSZ//LSCM73+8YSZ tested at $950^{\circ} \mathrm{C}$ with $0.5 \mathrm{~V}$ from 0 to $80 \mathrm{~h}$ : a) in air, and b) in $\mathrm{Ar}-3 \% \mathrm{H}_{2}-3 \% \mathrm{H}_{2} \mathrm{O}$. For clarity, only five spectra are shown.

Fig. 10. Comparison plots of resistance (ohmic and non-ohmic) changes with time (80h) for the symmetrical cell of configuration LSCM73+8YSZ//8YSZ//LSCM73+8YSZ tested at $0.5 \mathrm{~V}$ in air and $\mathrm{Ar}-3 \% \mathrm{H}_{2}-3 \% \mathrm{H}_{2} \mathrm{O}$.

Fig. 11. SEM micrographs of the symmetrical cell of configuration LSCM73+8YSZ//8YSZ//LSCM73+8YSZ (anode surface): a) LSCM73+8YSZ and 8YSZ interface b) as-sintered in air, c) tested in air, and d) tested in $\mathrm{Ar}-3 \% \mathrm{H}_{2}-3 \% \mathrm{H}_{2} \mathrm{O}$. 
Fig. 12. SEM micrograph of the anode-side electrolyte interface after testing and removing LSCM73 layer: a) air and b) $\mathrm{Ar}-3 \% \mathrm{H}_{2}-3 \% \mathrm{H}_{2} \mathrm{O}$. 
$28 \mathrm{CH}_{4} 8$ со $8 \mathrm{H}_{2}$ OO $\mathrm{O}_{2}$

$28 \mathrm{cH}_{4} 8 \mathrm{co} 8 \mathrm{H}_{2} 00 \mathrm{O}_{2}$

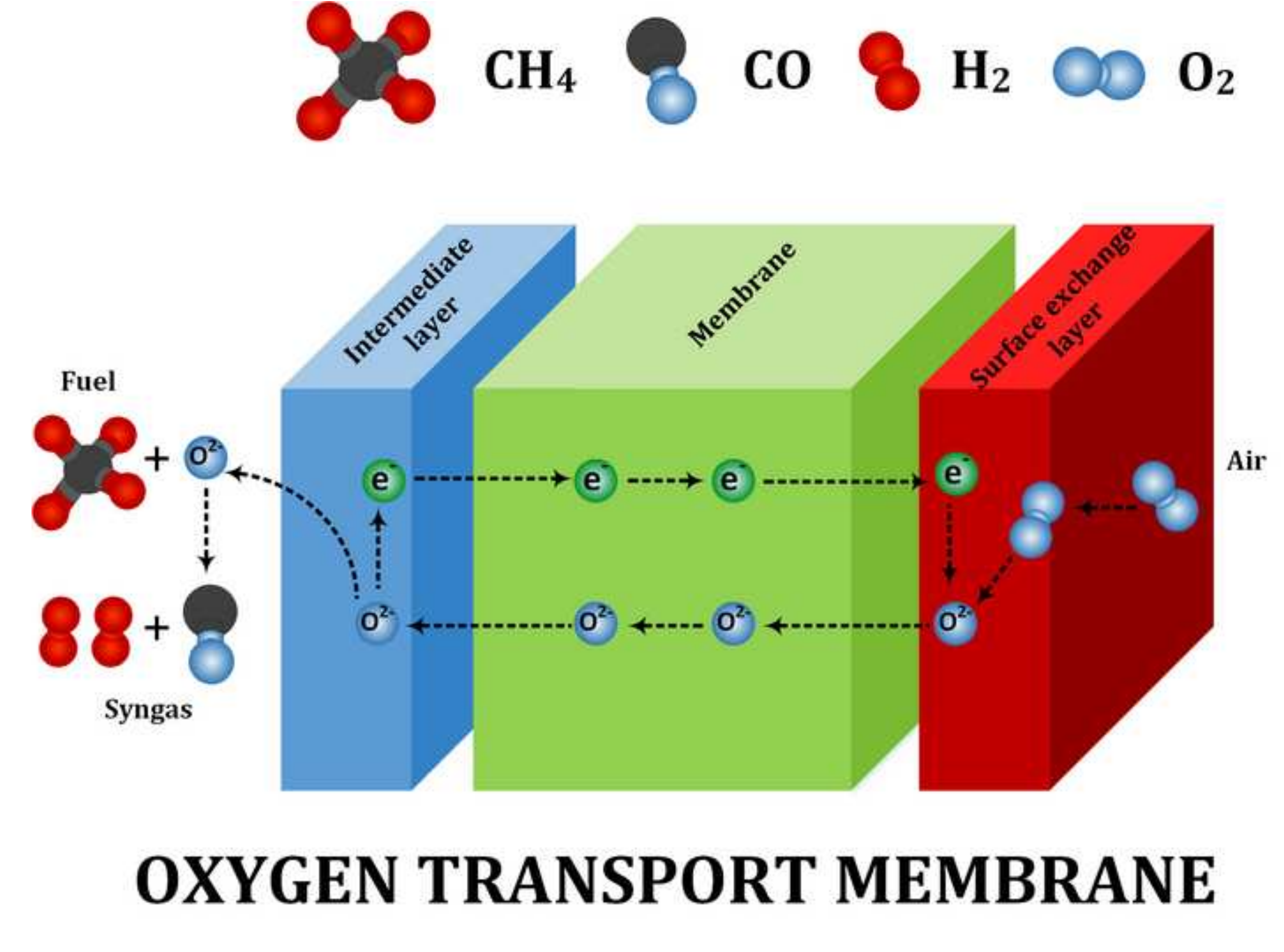

OXYGEN TRANSPORT MEMBRANE

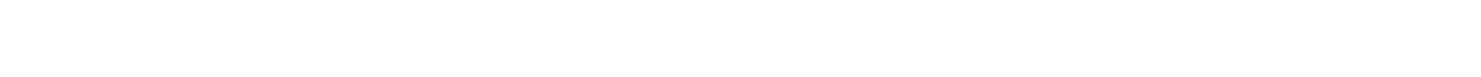

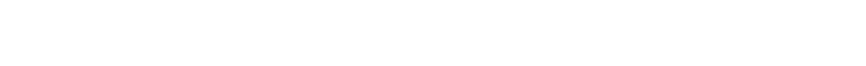




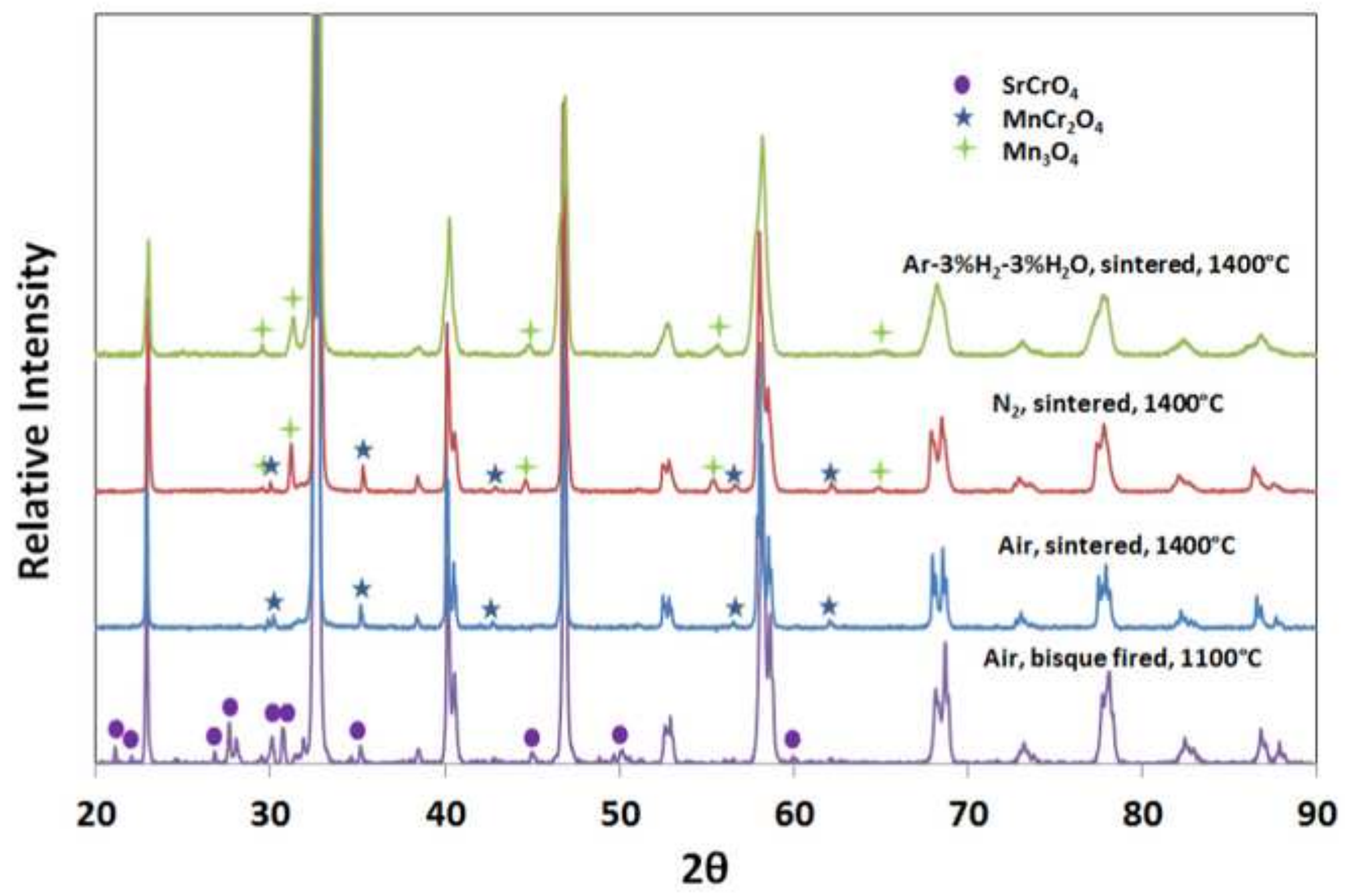




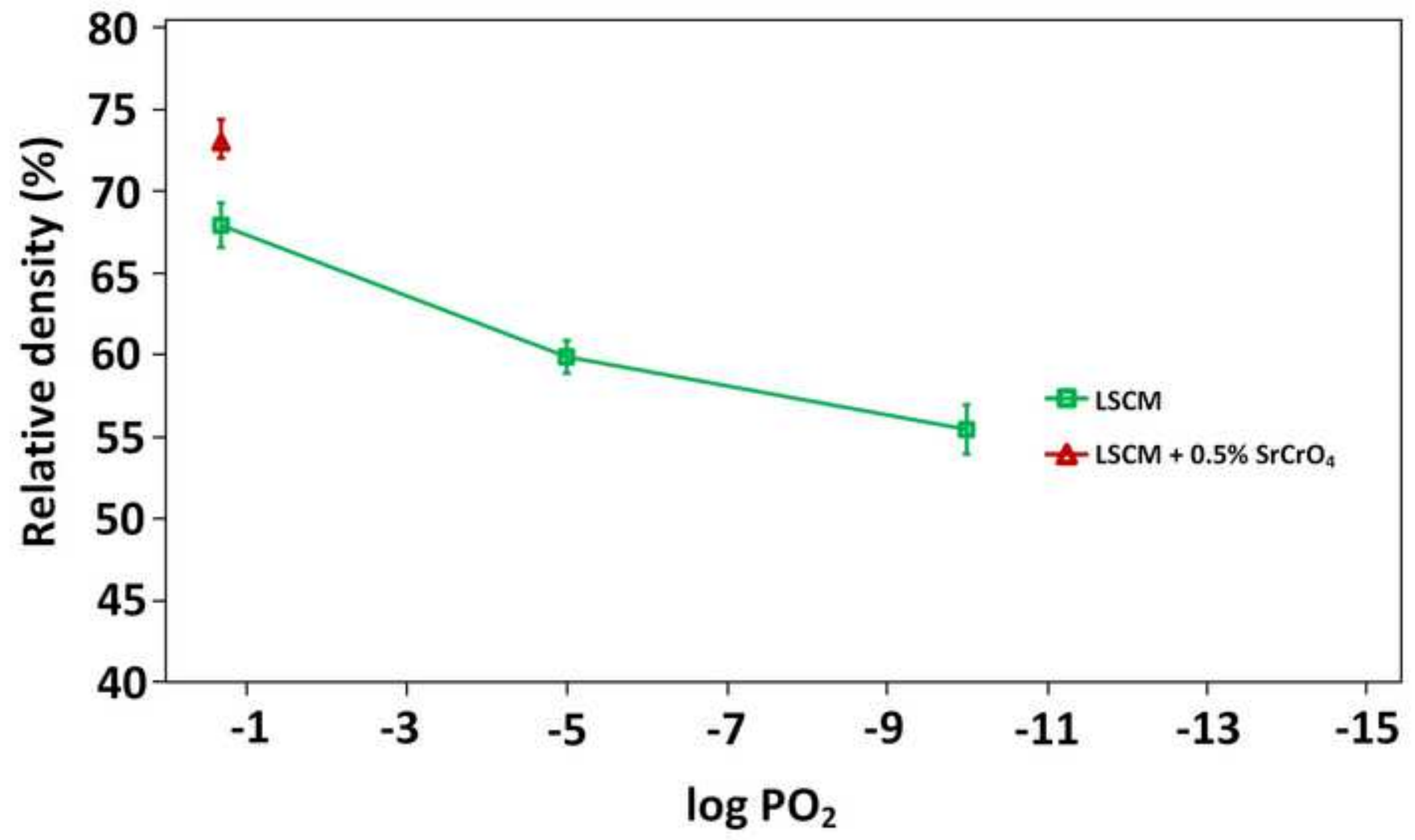



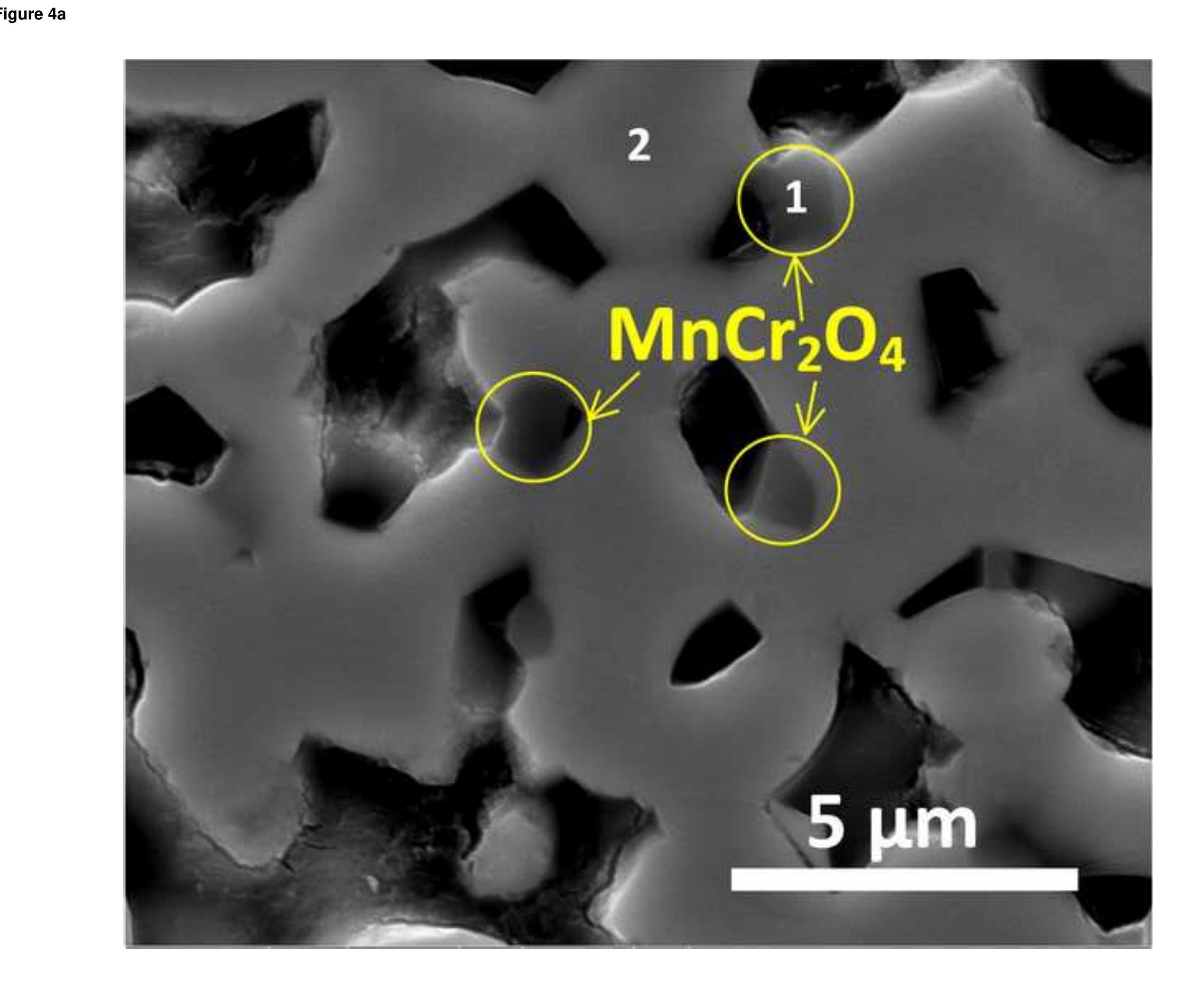

a
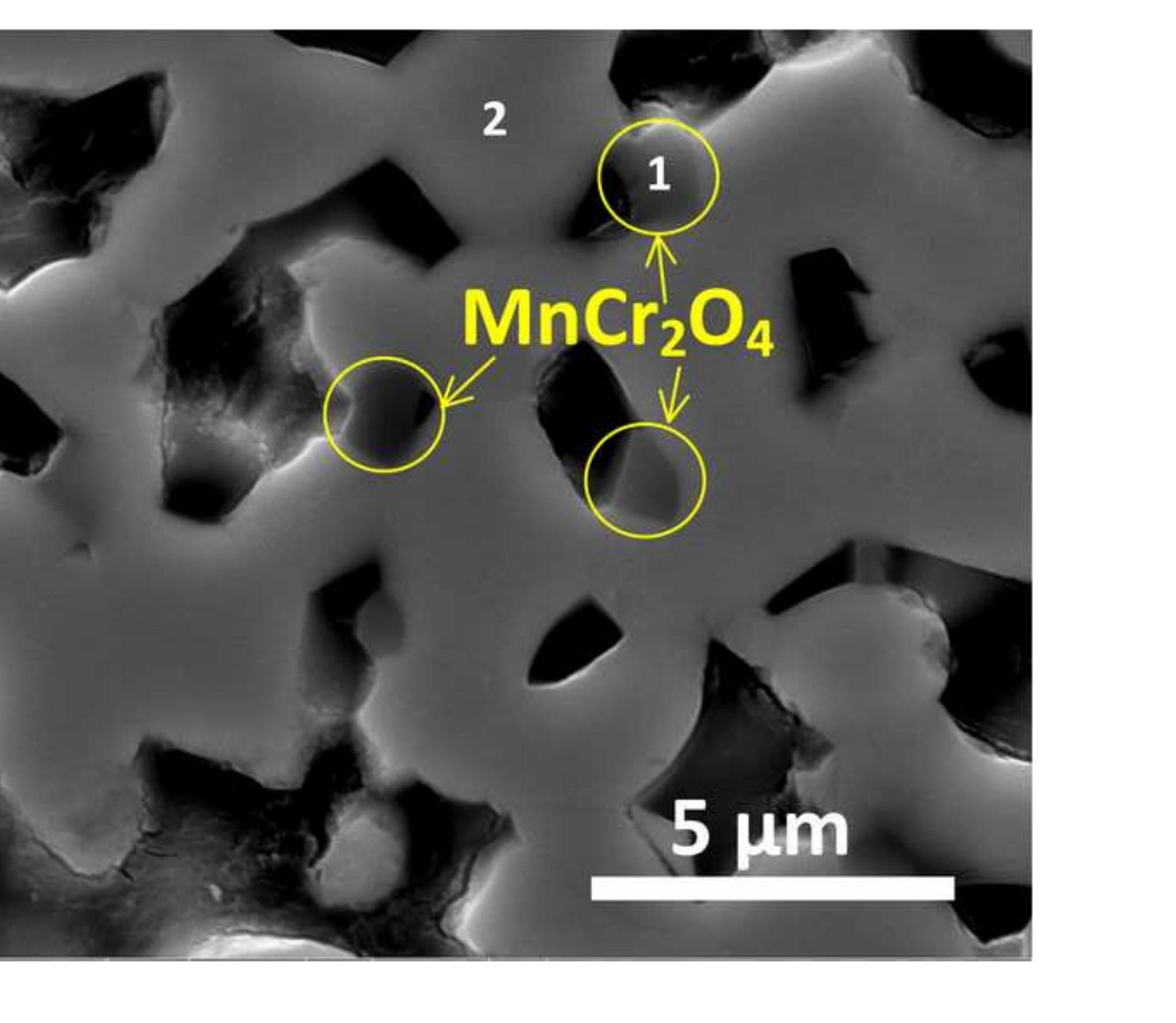

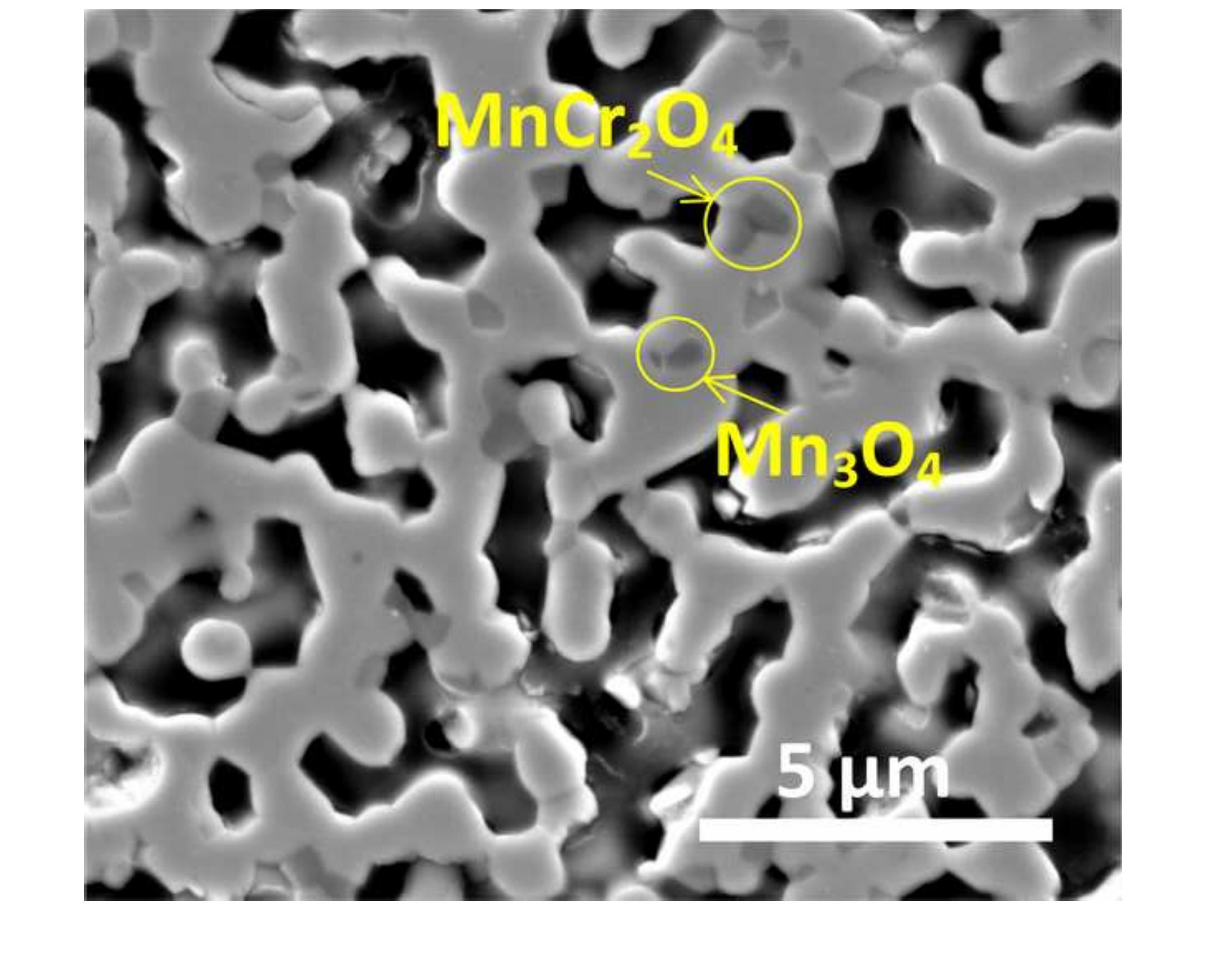


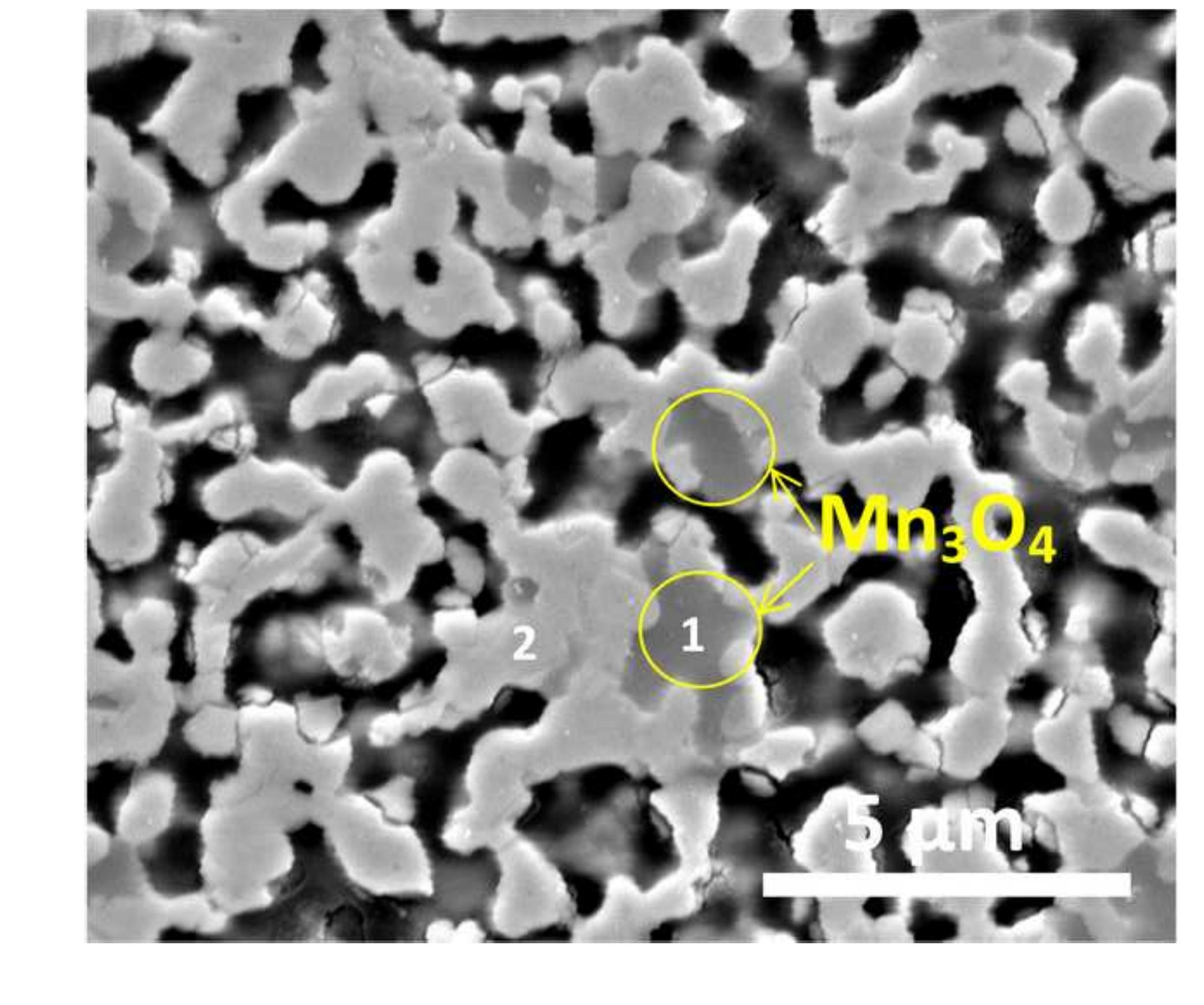

\section{(}
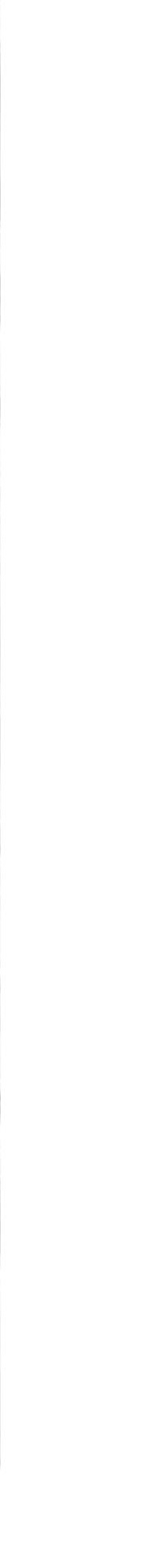

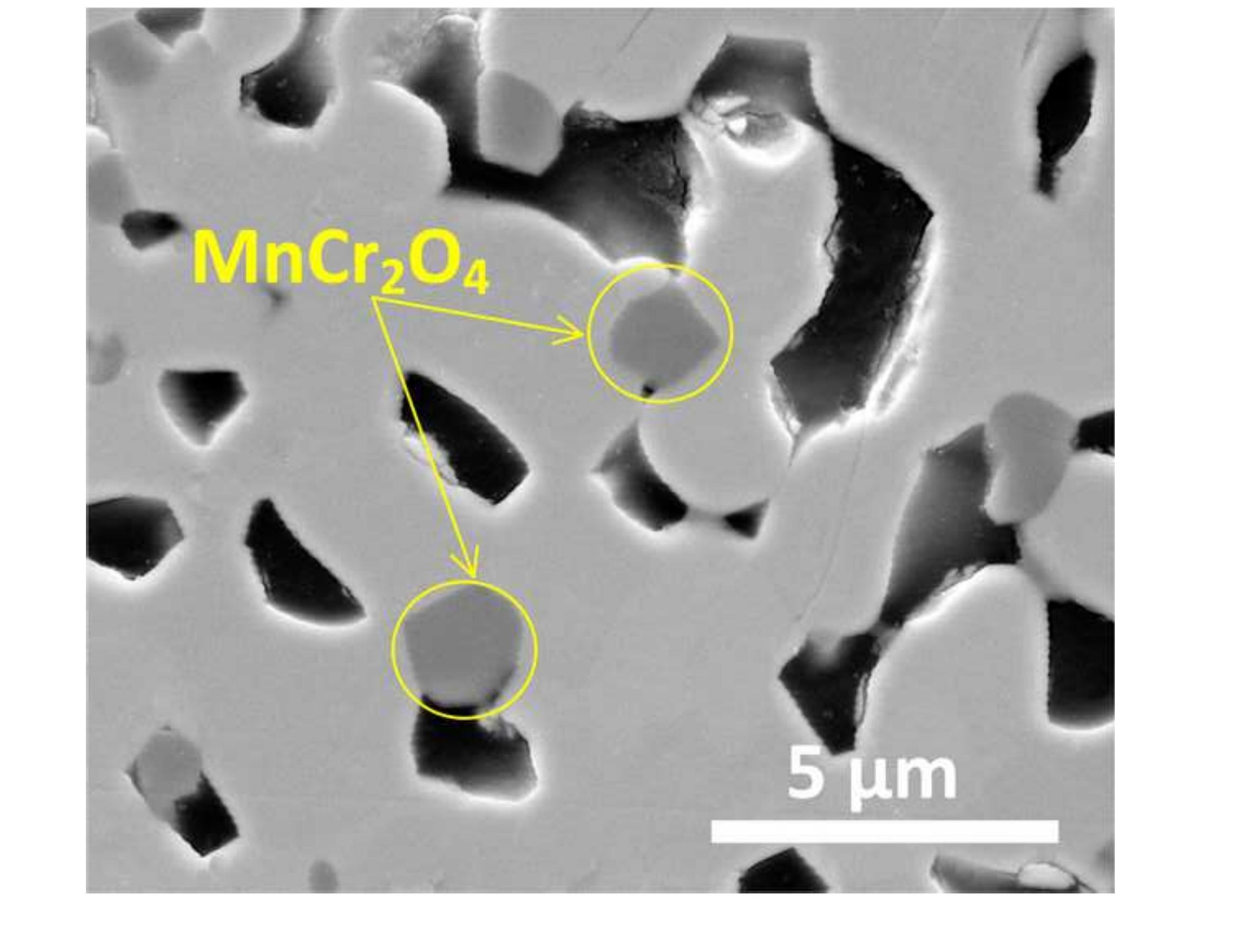
$d$
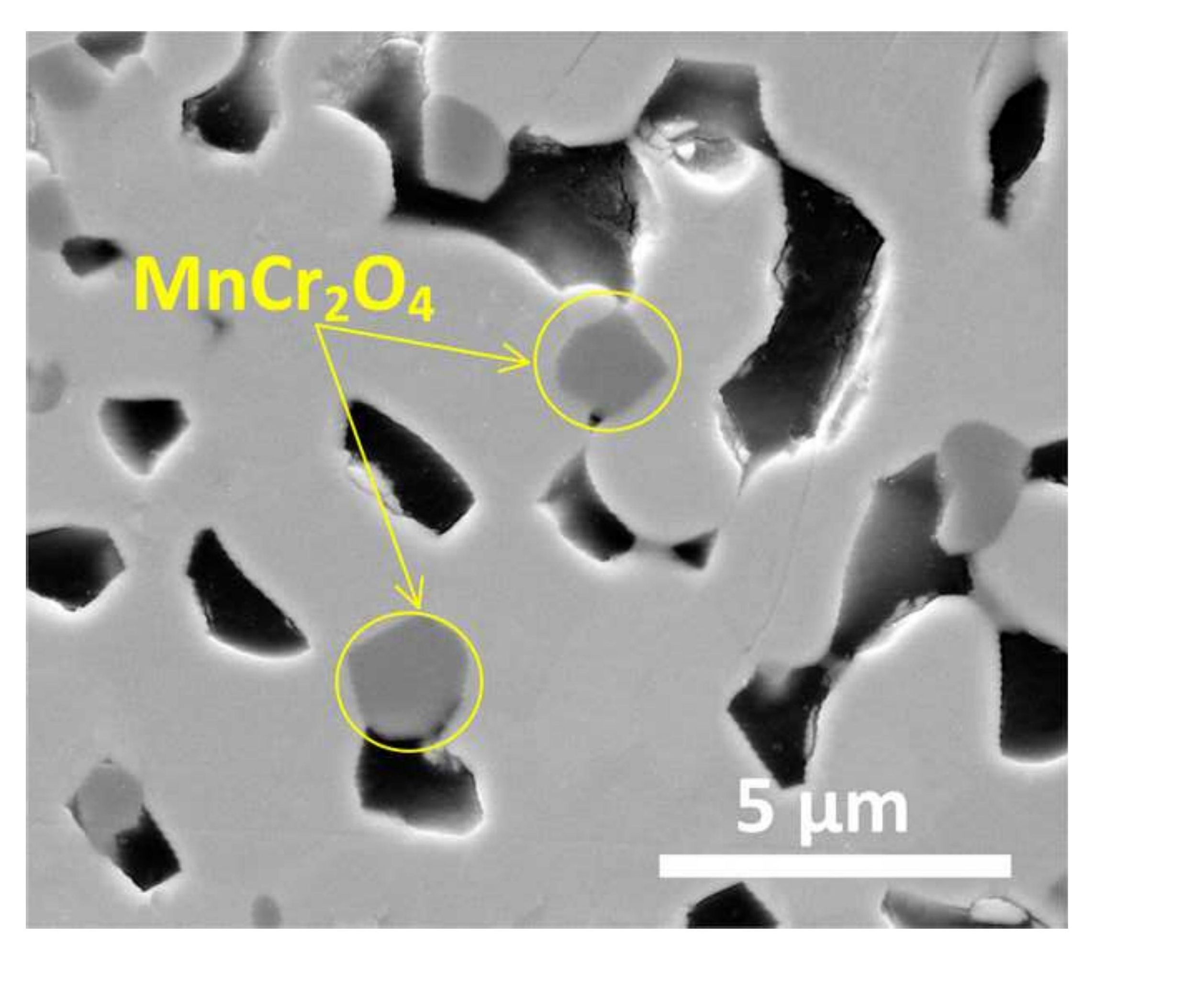


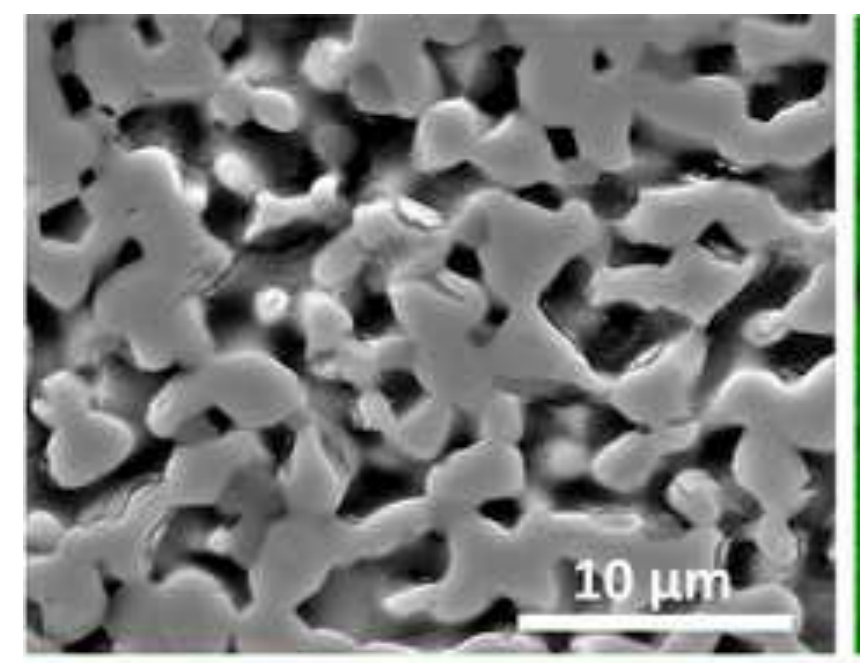

La
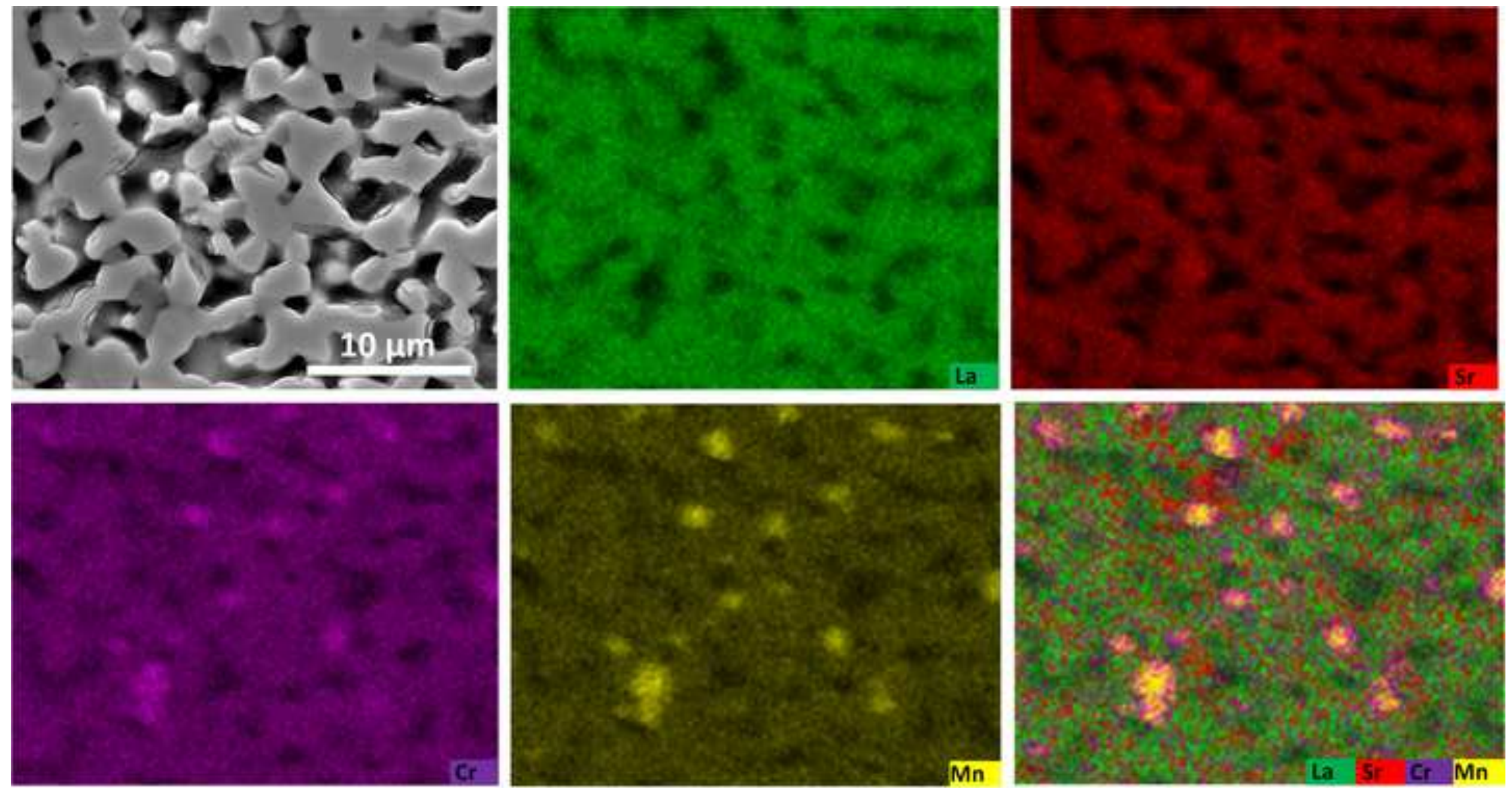

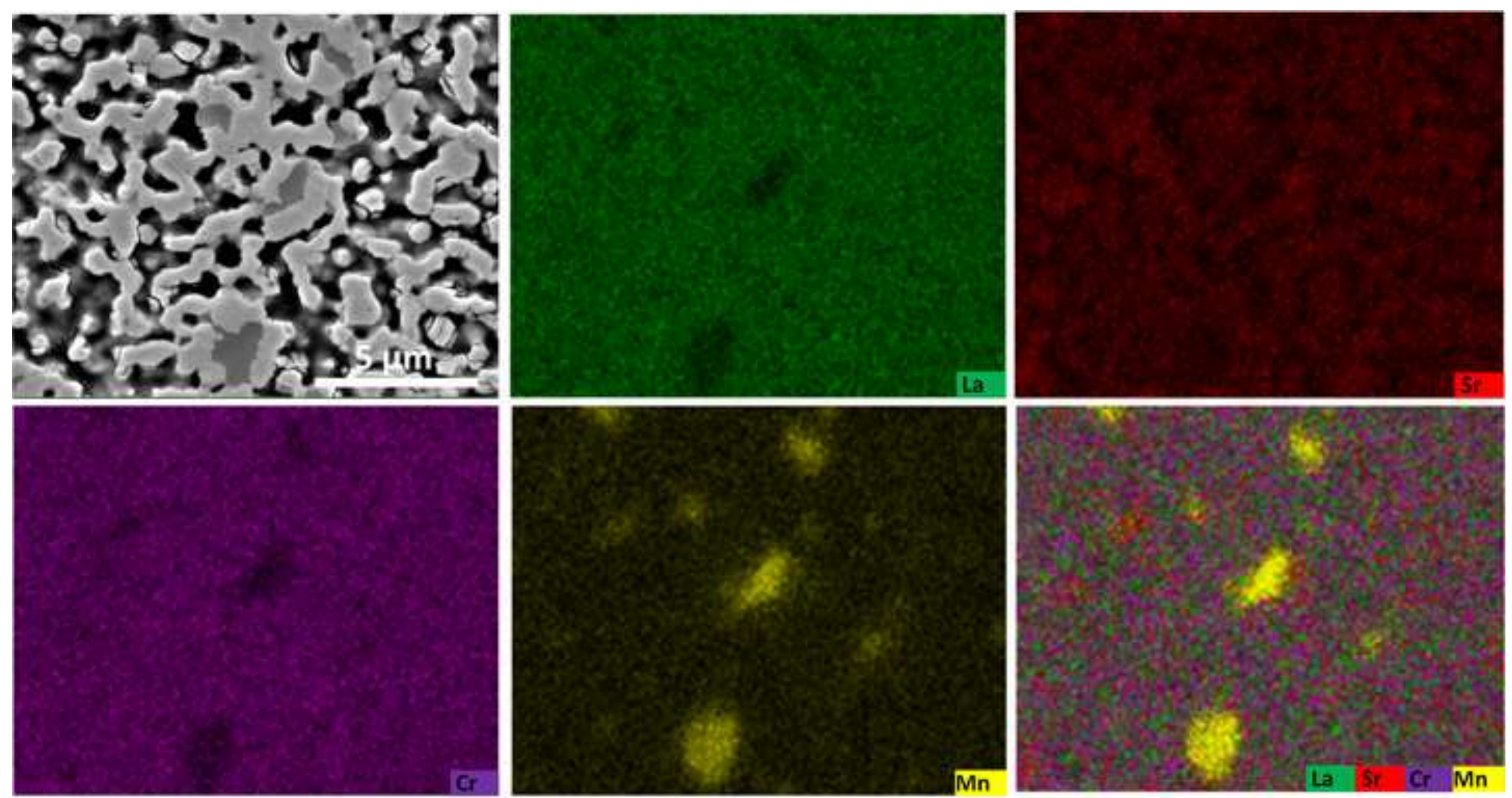

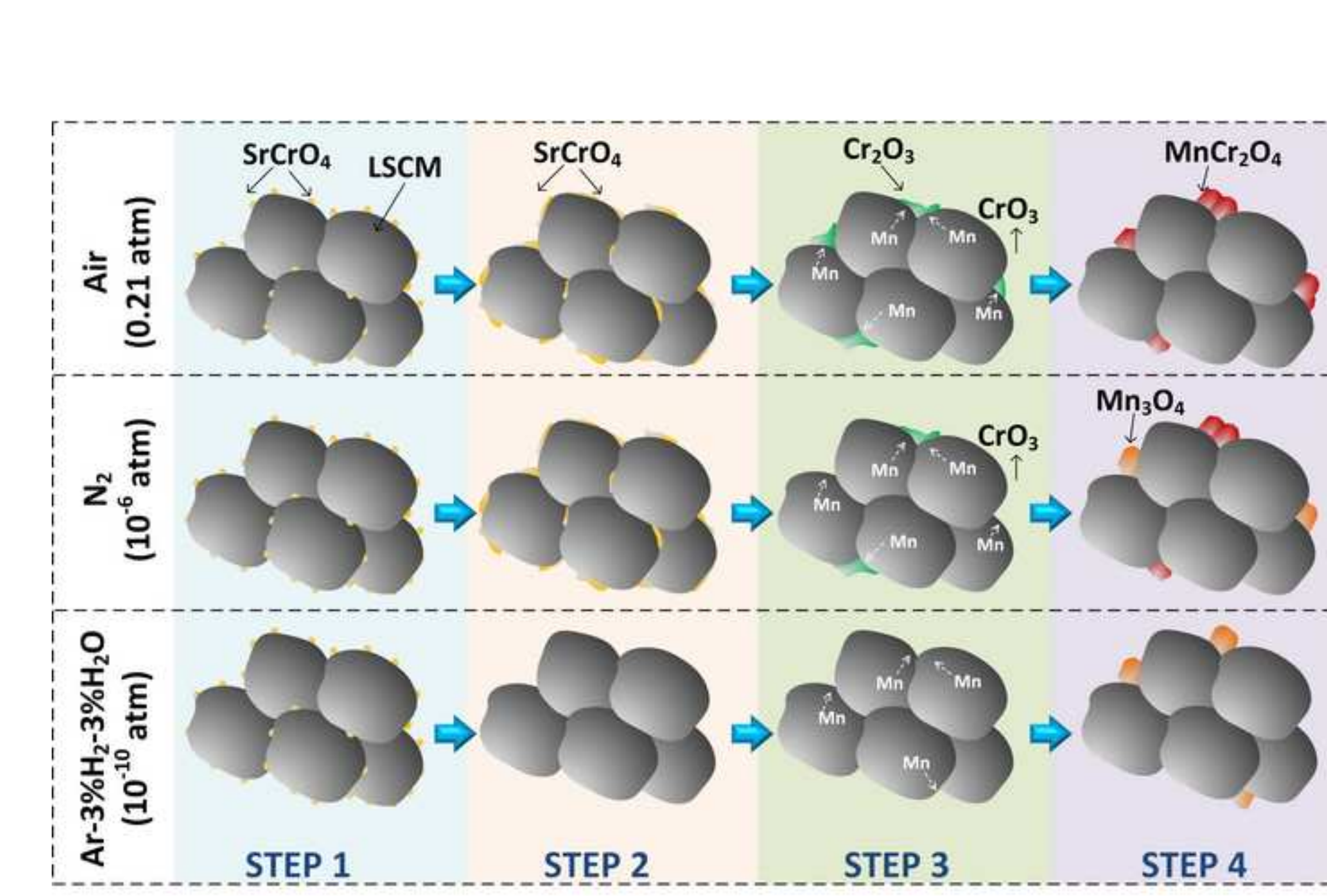

STEP 1

STEP 2

STEP 3

STEP 4 


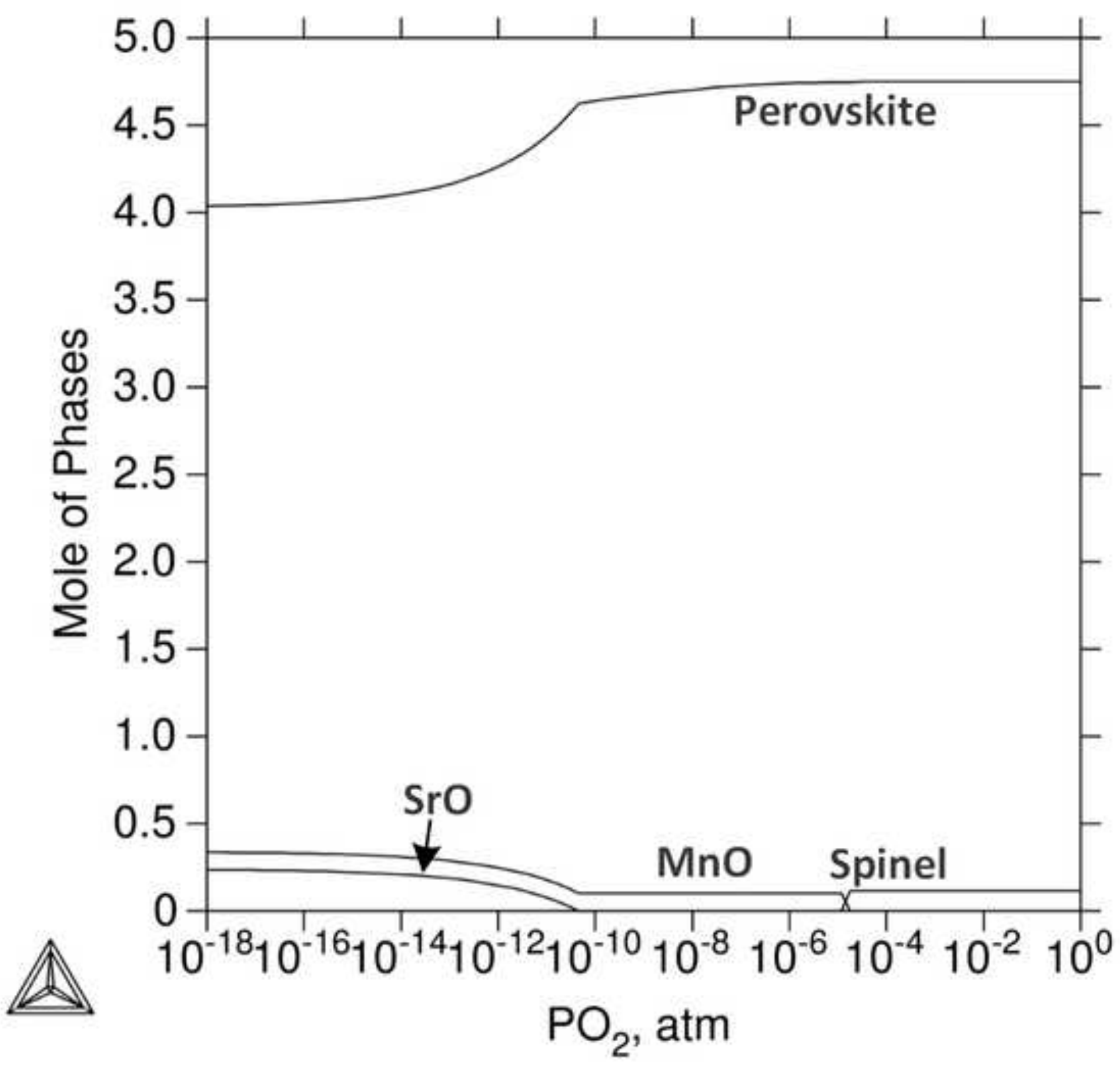




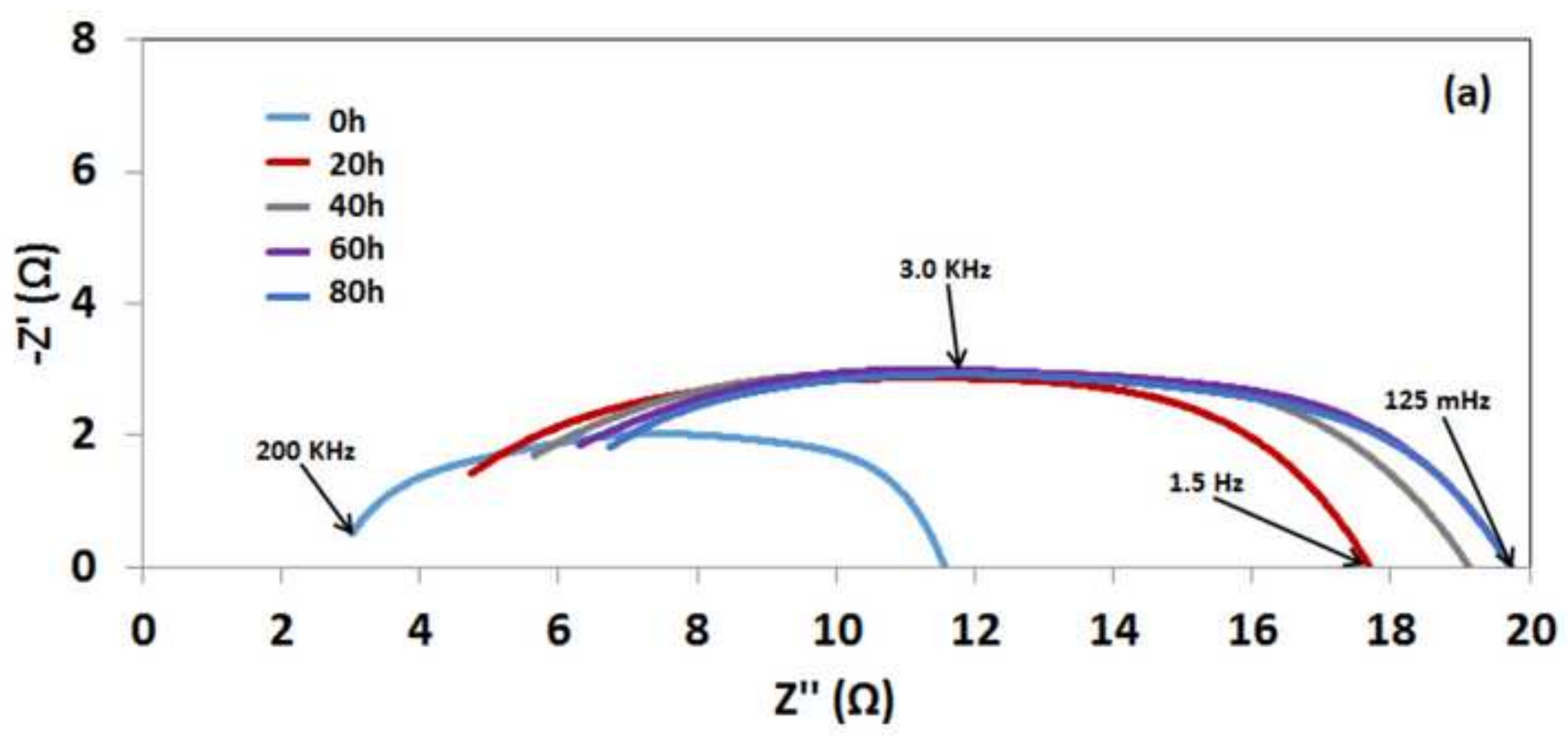




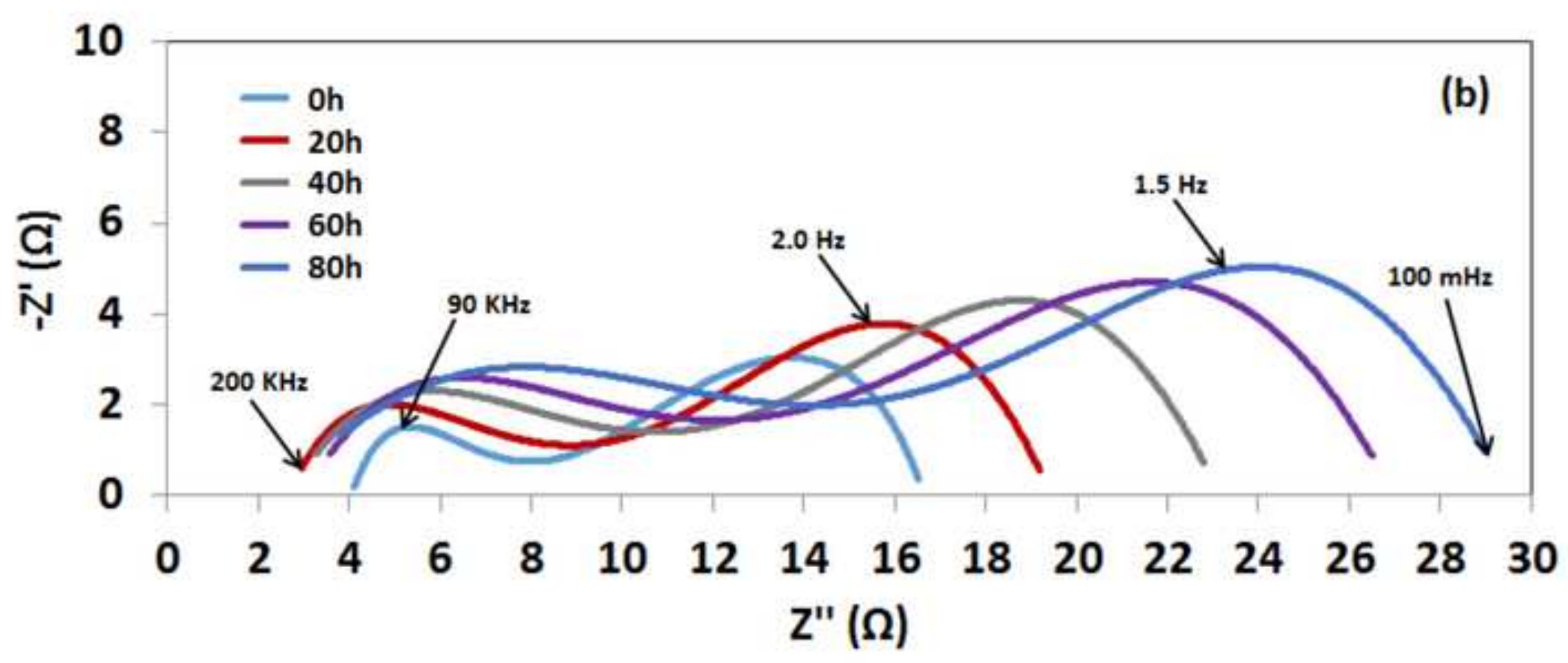




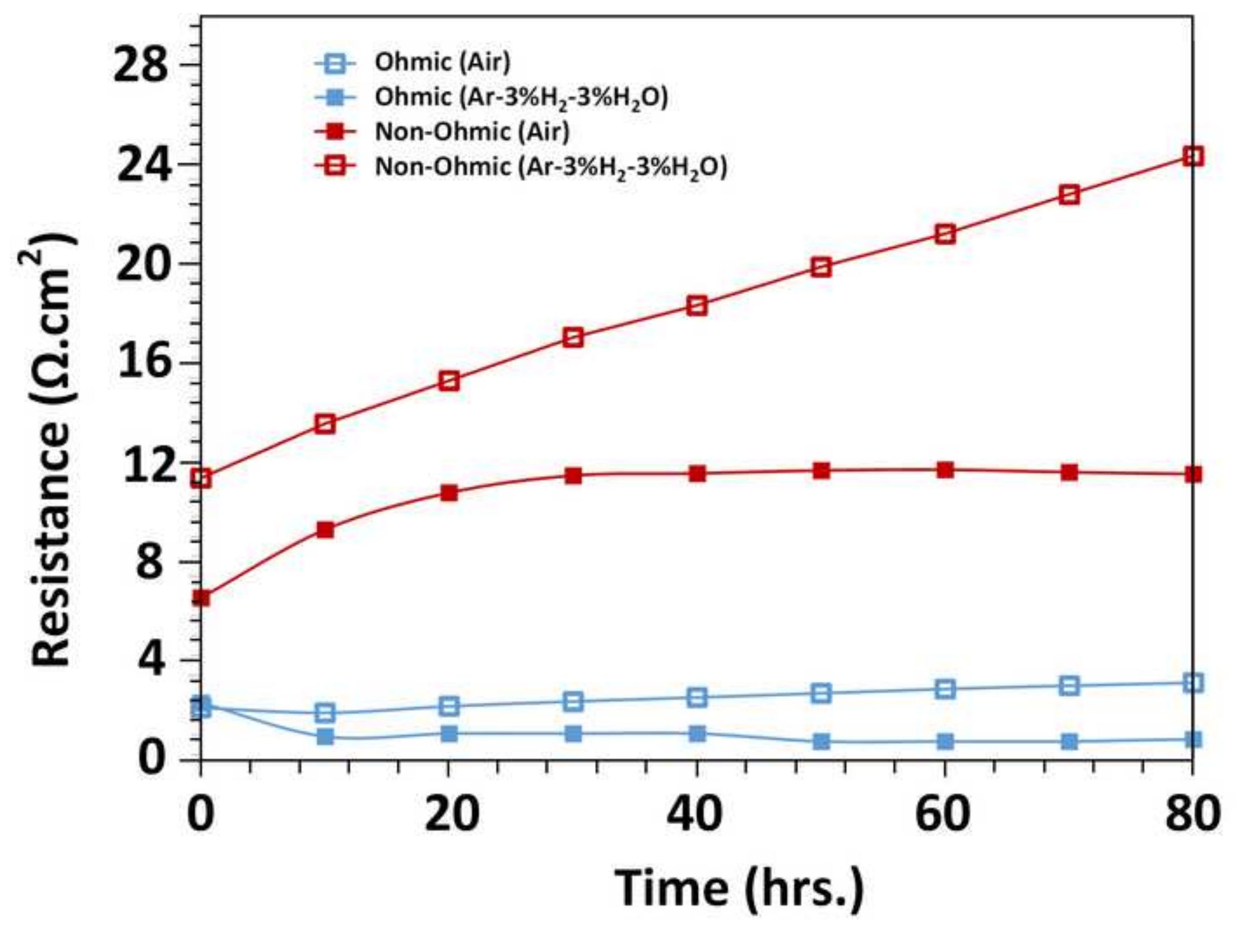




\section{(a)}

\section{LSCM+8YSZ}

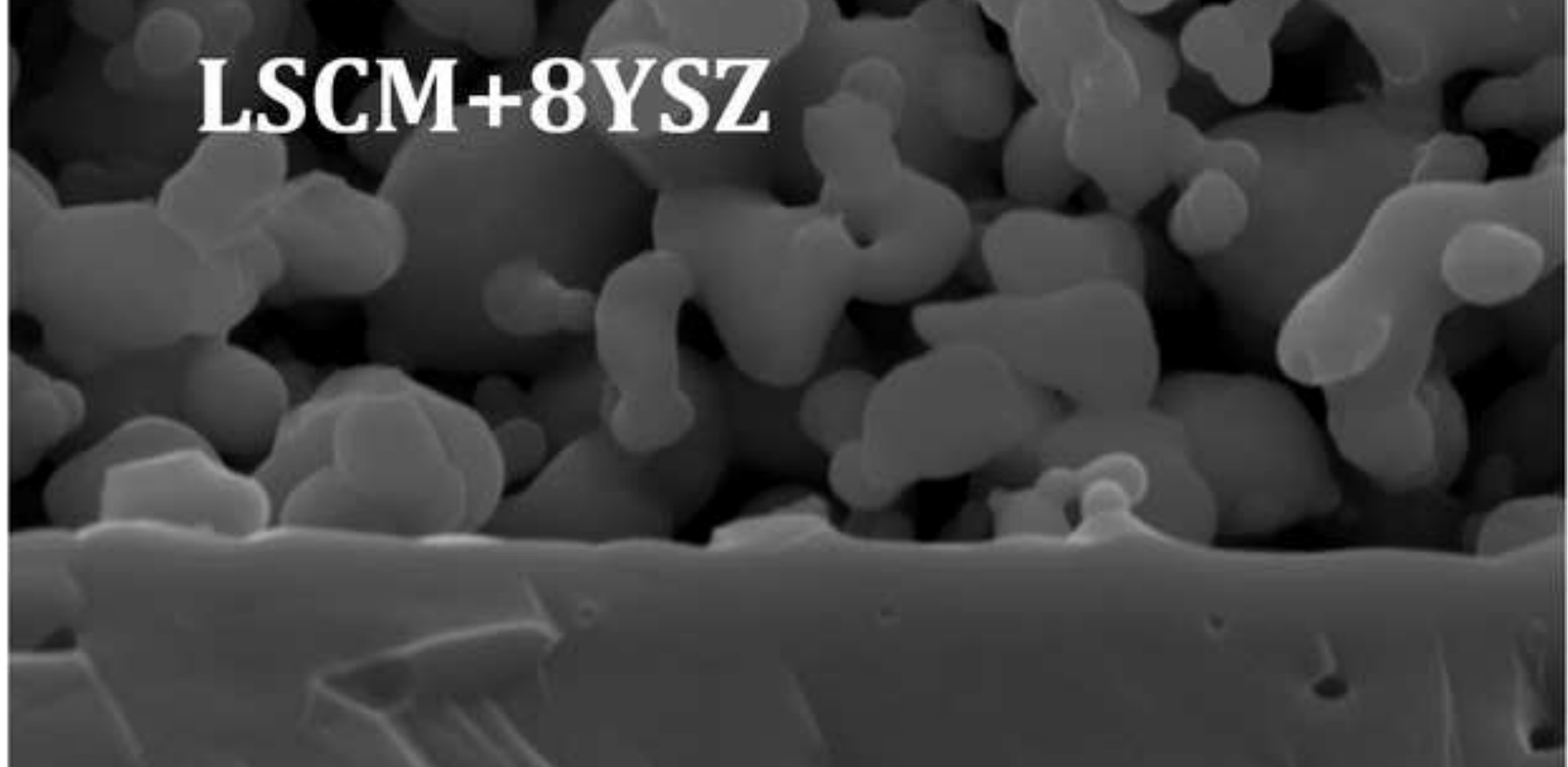

\section{YSZ}

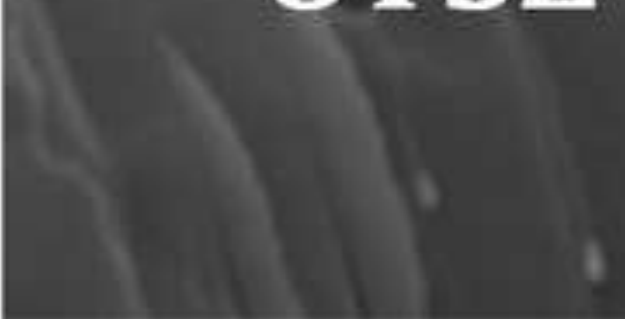

\section{$3 \mu \mathrm{m}$}




\section{(c)}

8YSZ

\section{LSCM \\ (Sr: La $0.43 \pm 0.04$ )}

$500 \mathrm{~nm}$

$500 \mathrm{~nm}$

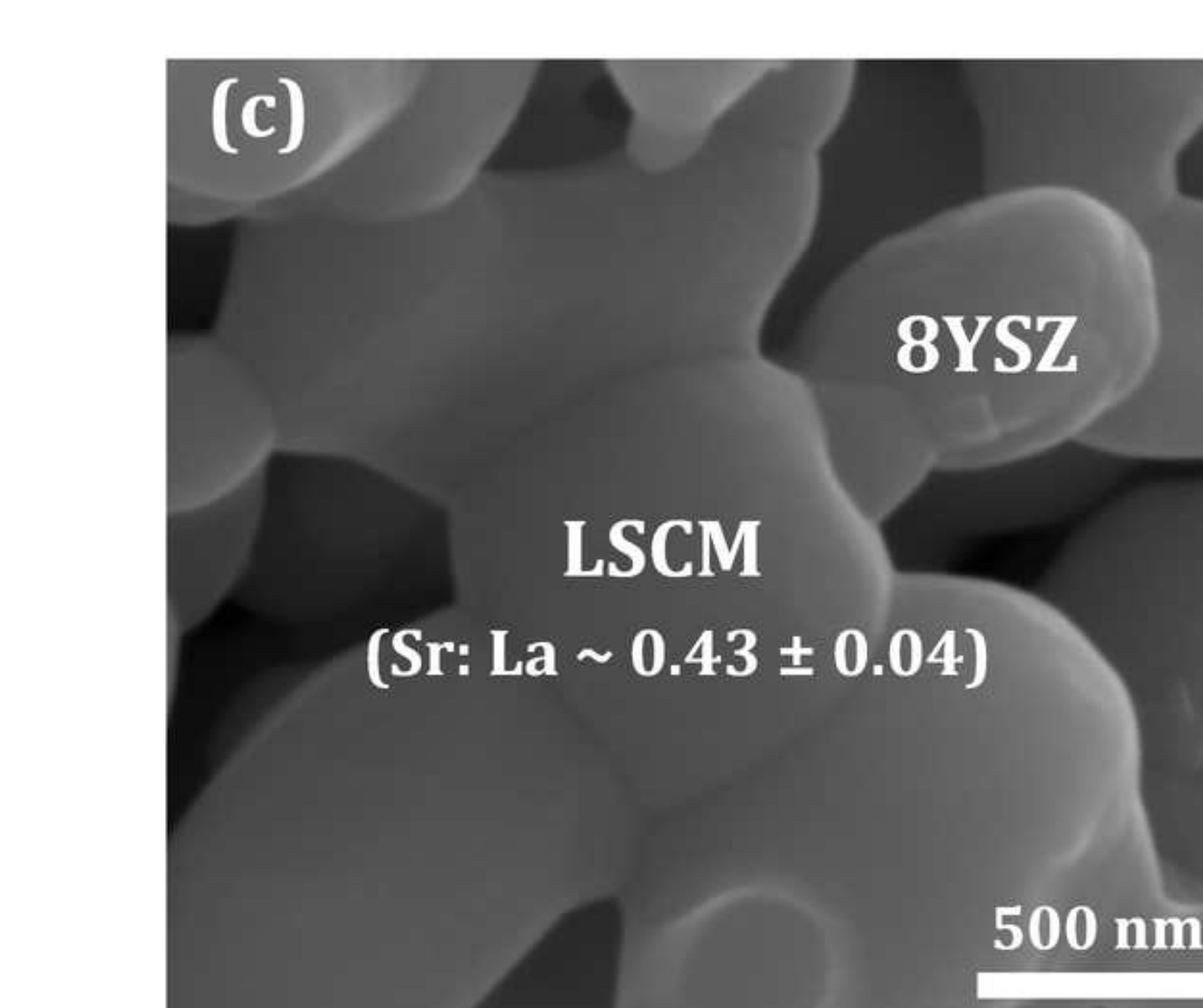

$\square$

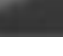




\section{YSZ}

\section{LSCM \\ (Sr: La $0.65 \pm 0.05$ )}

\section{$500 \mathrm{~nm}$ \\ 500 nim}

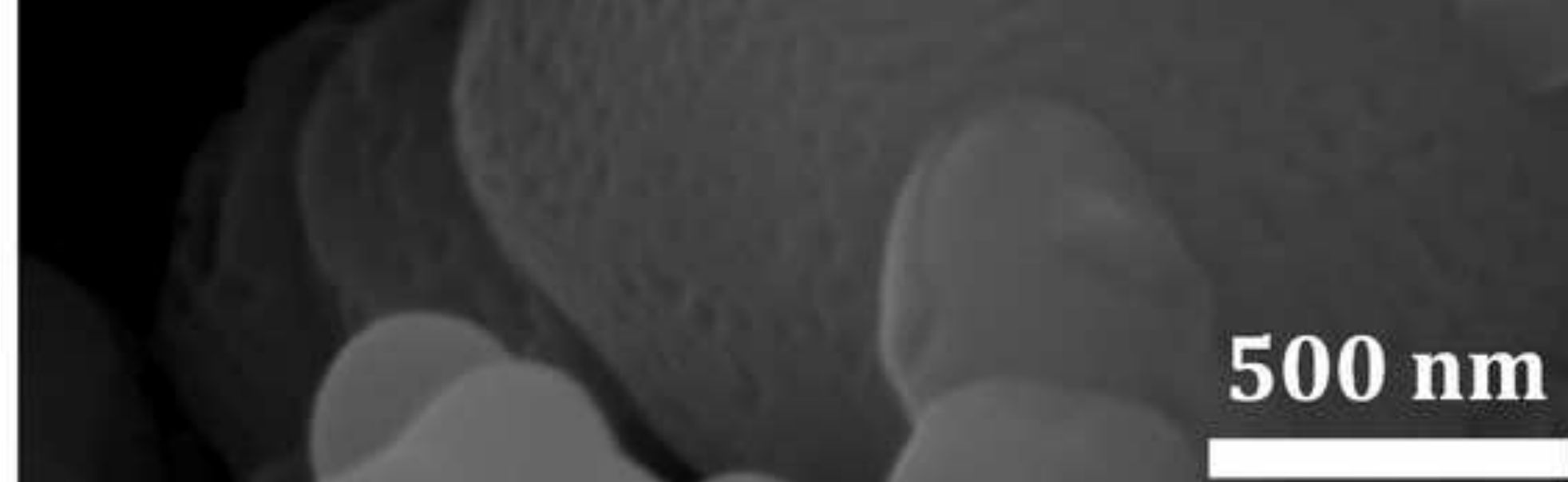



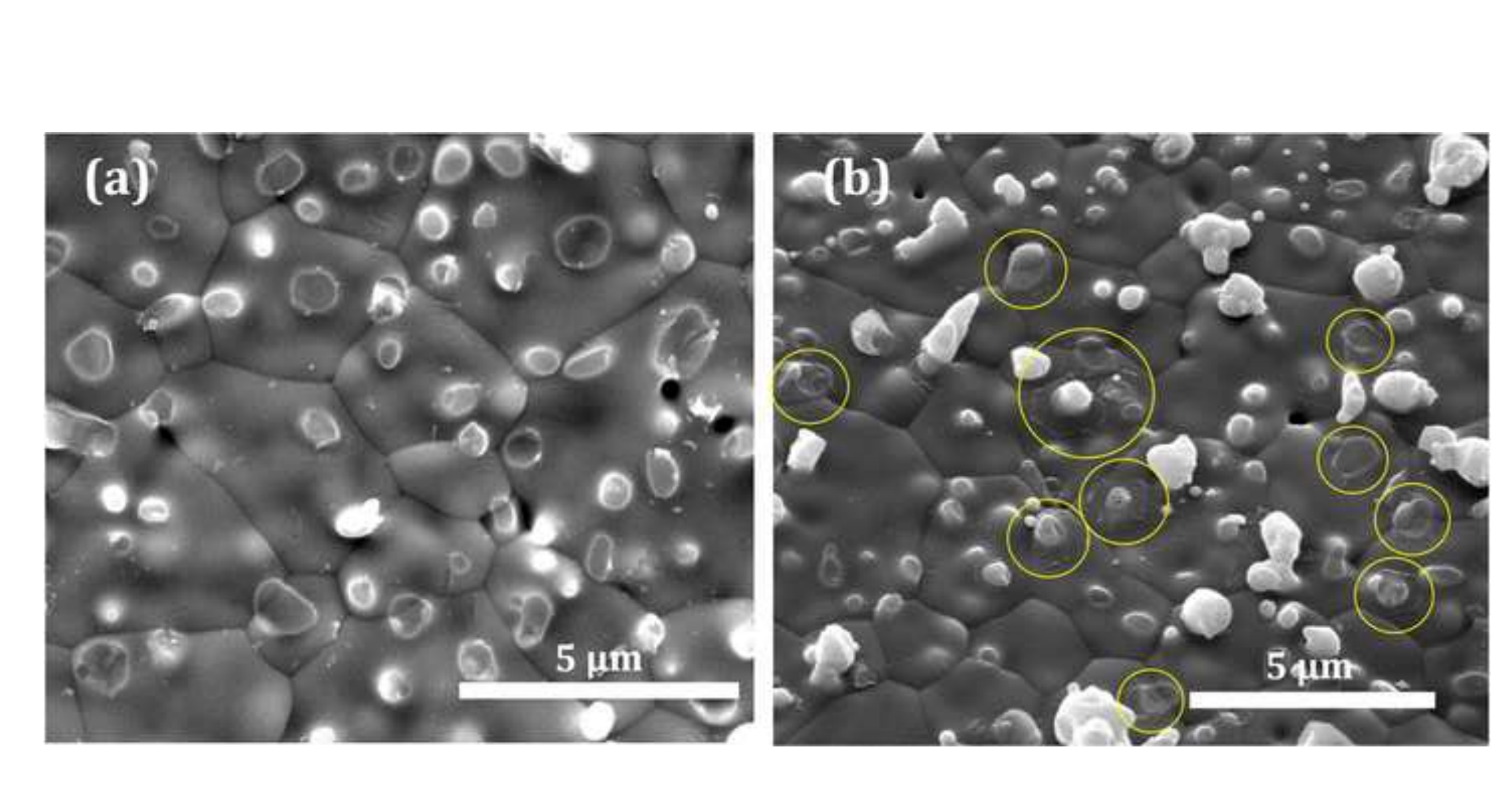

.
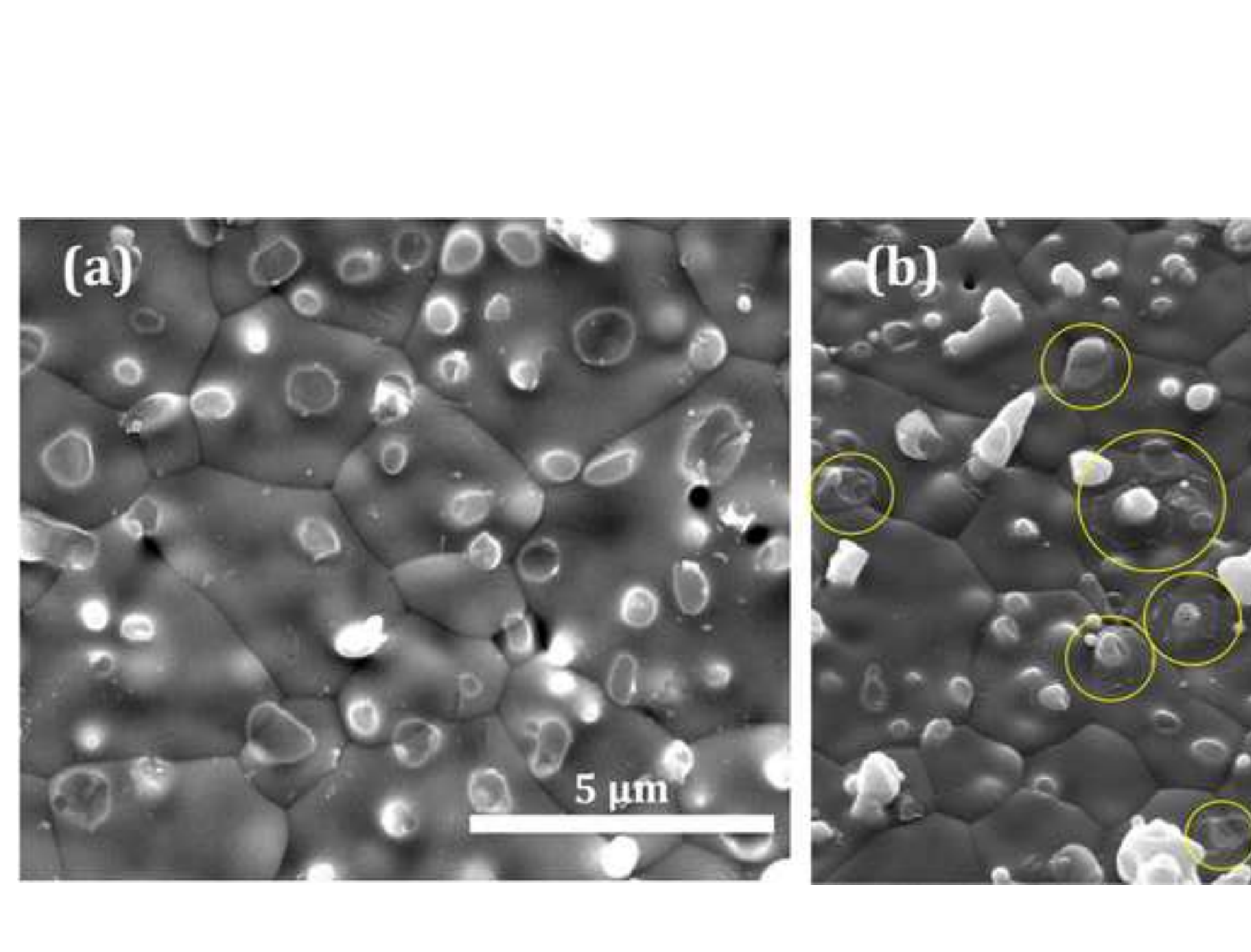
Tables

Table 1. SEM-EDS elemental analysis of LSCM73 sintered in air.

\begin{tabular}{lcccc}
\hline Element & La (at. \%) & Sr (at. \%) & Cr (at. \%) & Mn (at. \%) \\
\hline Area 1 (Mn-Cr-spinel) & $8.1 \pm 1.0$ & $2.7 \pm 4.3$ & $51.6 \pm 1.1$ & $37.6 \pm 4.6$ \\
Area 2 (Bulk) & $37.8 \pm 0.1$ & $16.4 \pm 0.4$ & $31.7 \pm 0.2$ & $13.7 \pm 0.3$ \\
\hline
\end{tabular}

Table 2. SEM-EDS elemental analysis of LSCM73 sintered in $\mathrm{Ar}-3 \% \mathrm{H}_{2}-3 \% \mathrm{H}_{2} \mathrm{O}$.

\begin{tabular}{ccccc}
\hline Element & La (at. \%) & Sr (at. \%) & Cr (at. \%) & Mn (at. \%) \\
\hline Area 1 (Mn-oxide) & $10.2 \pm 3.0$ & $5.6 \pm 4.3$ & $11.4 \pm 2.3$ & $70.8 \pm 3.9$ \\
Area 2 (Bulk) & $35.4 \pm 0.9$ & $16.4 \pm 2.2$ & $32.9 \pm 0.4$ & $15.3 \pm 0.3$ \\
\hline
\end{tabular}

